NonCommercial-NoDerivatives 4.0 International

\title{
Biofuels and thermal barrier: A review on compression ignition engine performance, combustion and exhaust gas emission
}

\author{
K. Masera, A. K. Hossain* \\ Sustainable Environment Research Group (SERG), School of Engineering and Applied Science, \\ Aston University, Aston Triangle, Birmingham B4 7ET, UK
}

\begin{abstract}
The performance of an internal combustion engine is affected when renewable biofuels are used instead of fossil fuels in an unmodified engine. Various engine modifications were experimented by the researchers to optimise the biofuels operated engine performance. Thermal barrier coating is one of the techniques used to improve the biofuels operated engine performance and combustion characteristics by reducing the heat loss from the combustion chamber. In this study, engine tests results on performance, combustion and exhaust emission characteristics of the biofuels operated thermal barrier coated engines were collated and reviewed. The results found in the literature were reviewed in three scenarios: (i) uncoated versus coated engine for fossil diesel fuel application, (ii) uncoated versus coated engine for biofuels (and blends) application, and (iii) fossil diesel use on uncoated engine versus biofuel (and blends) use on coated engine. Effects of injection timing, injection pressure and fuel properties on thermal barrier coatings were also discussed. The material type, thickness and properties of the coating materials used by the research community were presented. The effectiveness and durability of the coating layer depends on two key properties: low thermal conductivity and high thermal expansion coefficient. The current study showed that thermal barrier coatings could potentially offset the performance drop due to use of biofuels in the compression ignition engines. Improvements of up to $4.6 \%$ in torque, $7.8 \%$ in power output, $13.4 \%$ in brake specific fuel consumption, $15.4 \%$ in brake specific energy consumption and $10.7 \%$ in brake thermal efficiency were reported when biofuels or biofuel blends were used in the thermal barrier coated engines as compared to the uncoated engines. In coated engines, peak cylinder pressure and exhaust gas temperature were increased by up to 16.3 bar and $14 \%$ respectively as compared to uncoated condition. However, changes in the heat release rates were reported to be between $-27 \%$ and $+13.8 \%$ as compared to uncoated standard engine. Reductions of $\mathrm{CO}, \mathrm{CO}_{2}, \mathrm{HC}$ and smoke emissions were reported by up to $3.8 \%$, $11.1 \%, 90.9 \%$ and $63 \%$ respectively as compared to uncoated engines. Significant decreases in the PM emissions were also reported due to use of thermal barrier coatings in the combustion chamber. In contrast, at high speed and at high load operation, increase in the $\mathrm{CO}$ and $\mathrm{CO}_{2}$ emissions were also reported in coated engines. Coated engines gave higher $\mathrm{NO}_{\mathrm{x}}$ emissions by about $4-62.9 \%$ as compared to uncoated engines. Combined effects of thermal barrier coatings and optimisation of fuel properties and injection parameters produced further performance and emissions advantages compared to only thermal barrier coated engines. Overall, current review study showed that application of thermal barrier coatings in compression ignition engines could be beneficial when biofuels or biofuel blends are used instead of standard fossil diesel. However, more research is needed combining coatings, types of biofuels and other engine modifications to establish a concrete conclusion on the effectiveness of the thermal barrier when biofuels are used in the compression ignition engine. Reduction of $\mathrm{NO}_{\mathrm{x}}$ emissions is another important $\mathrm{R} \& \mathrm{D}$ area.
\end{abstract}

Keywords: Thermal barrier coatings; Low heat rejection engine; CI engine; Biofuels; Combustion; Exhaust emission. 
* Corresponding author. Tel.: 44(0)1212043041; fax: 44(0)1212043683.

E-mail address: a.k.hossain@aston.ac.uk (A. K. Hossain).

\section{List of Abbreviations}

BSEC: Brake Specific Energy Consumption

BSFC: Brake Specific Fuel Consumption

BTE: Brake Thermal Efficiency

BTL: Biomass to Liquid

CA: Crank Angle

CB: Coated Biofuel

CD: Coated Diesel

CI: Compression Ignition

CL: Cooling Load

CSO: Cotton Seed Oil

CSOB: Cotton Seed Oil Biodiesel

EGE: Exhaust Gas Emission

EGT: Exhaust Gas Temperature

GHG: Greenhouse Gas

HC: Hydrocarbon

HCCI: Homogeneous Charge Compression Ignition

IC: Internal Combustion

JO: Jatropha Oil

JOB: Jatropha Oil Biodiesel

LHR: Low Heat Rejection

Mo: Molybdenum

MO: Mohr Oil

MOB: Mohr Oil Biodiesel

MRICPR: Maximum Rate of In-Cylinder Pressure Rise

NT: Normal Temperature (without preheating)

PM: Particulate Matter

PT: Preheated Temperature

RBO: Rice Bran Oil

SI: Spark Ignition

TBC: Thermal Barrier Coating

TEC: Thermal Expansion Coefficient

TSOB: Tobacco Seed Oil Biodiesel

UB: Uncoated Biofuel

UD: Uncoated Diesel

VE: Volumetric Efficiency

\section{Contents}

Abstract.

List of Abbreviations

1. Introduction

2. Thermal Barrier Coatings and Materials Properties

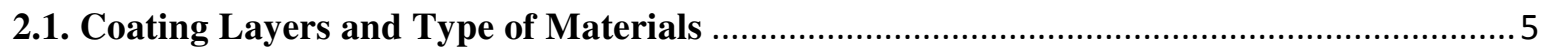

3. Coatings and Engine Performance Characteristics ............................................................ 6

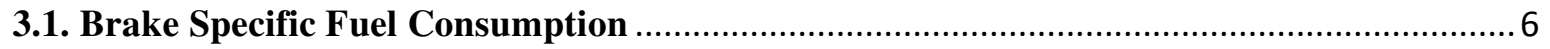

3.2. Brake Specific Energy Consumption .......................................................................... 6

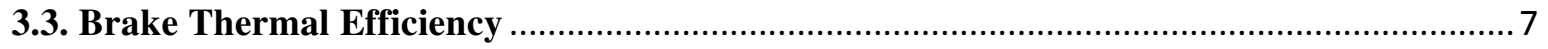

3.4. Engine Power 


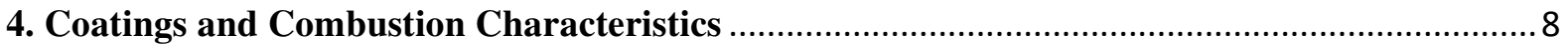

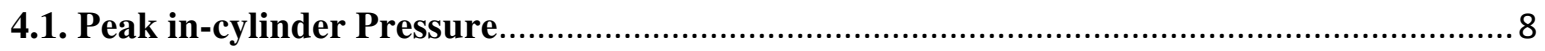

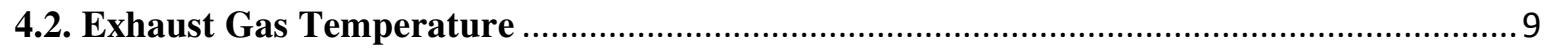

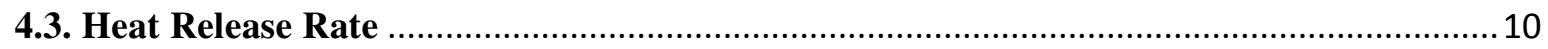

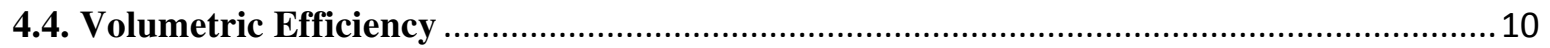

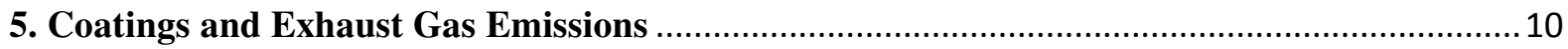

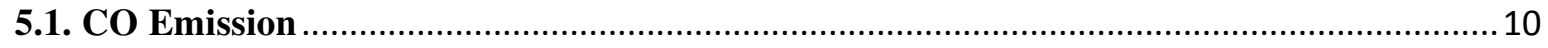

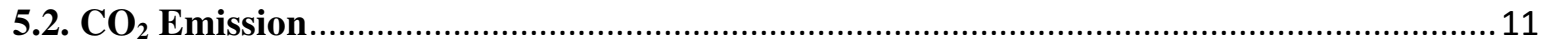

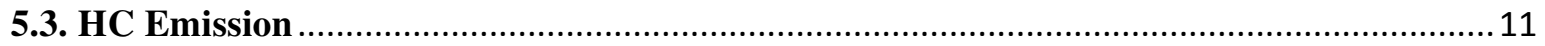

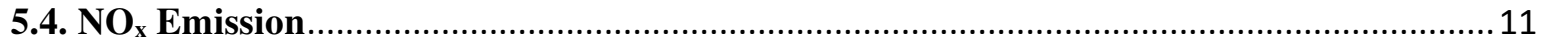

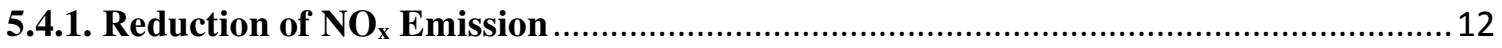

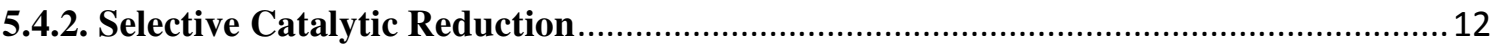

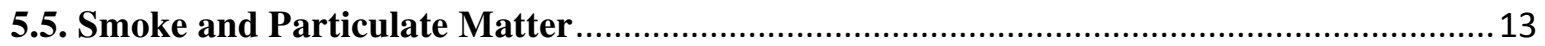

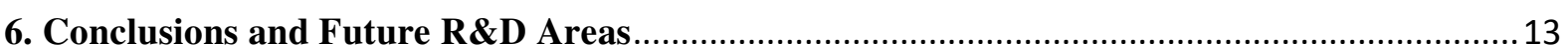

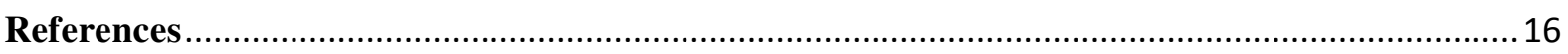

\section{Introduction}

About $80.7 \%$ of the world energy demand is met by using the fossil based fuels [1] releasing considerable amount of lifecycle greenhouse gas (GHG) emissions. It is a well-known fact that the rising levels of GHG emissions are directly linked to global warming. The greenhouse gases also pose a danger to the wellbeing of the living beings. Llyod and Cackete [2] reported adverse effects of internal combustion (IC) engine exhaust gas emissions on human health e.g. cancer, cardiovascular and respiratory diseases. Furthermore, fossil based fuels are also facing with other issues such as depletion of resources, limited refinery capacity and security of supply [3]. Alternative fuel sources such as renewable biofuels can substitute fossil fuels and offset GHG emissions. Renewable second generation liquid biofuels (e.g. biodiesel, bioethanol, biobutanol and biooil) can be produced from waste resources using various techniques such as transesterification (Figure 1), fermentation, BTL, and pyrolysis. Biofuels are green and emits lower GHG emissions than fossil based liquid fuels (e.g. kerosene, gasoline and diesel). However, use of liquid biofuels in an unmodified IC engine might deteriorate the engine performance and combustion characteristics due to the inferior physicochemical properties of the biofuels [4-9]. Researchers have been investigating various aspects of engine modifications in order to improve the engine performance and combustion parameters when biofuels are used instead of fossil fuels [3,10-13]. Thermal barrier coating (TBC) [also known as 'low heat rejection' (LHR)] is one of the modifications which could be applied when biofuels are used in the internal combustion engines. In IC engine, as a rule of thumb, approximately one-third of the total input energy is lost by heat transfer through the cooling fluid, and another third of the total energy is released through tail pipe, and the rest is transferred to the crank shaft in the form of mechanical power. According to the second law of thermodynamics, the thermal efficiency of an engine can be enhanced up 
to a certain level by minimising the energy losses to the surroundings [14-18]. The purpose of TBC is to reduce the heat losses from the combustion chamber of the engine to the surroundings (i.e. cooling system). Reduction of heat energy losses from the combustion chamber would mean more energy is available at the crank shaft [19]. Thermal barrier coatings can be applied on the surfaces of the components in the combustion chamber (piston crown, cylinder head and liner, inlet and exhaust valves). Research and development activities were carried out in various parts of the world to investigate how thermal barrier coatings affects the engine performance, combustion and exhaust gas emissions [12-14,1618,20-36] characteristics when various types of biofuels (and their blends) were used in the engine instead of fossil fuel. Until now, application of TBC is so far limited to some race engines [37] and gas turbines [38] using standard fuels.

The advantages and disadvantages of using the thermal barrier coatings on gas turbine performance were reviewed and available in the public domain [39,40]. Types of coating materials, their properties and effects of high temperature on coatings were discussed [41]. Jaichandar and Tamilporai [42] published an overview of various theoretical, experimental and simulation studies on low heat rejection (LHR) engines. They reviewed the effects of injection parameters on LHR engine performance characteristics. Hardly any review study could be found in the literature focusing on how TBC affects engine performance, combustion and exhaust emission characteristics when biofuels (and blends) are used instead of fossil fuels in an IC engine. In this study, a review study was carried out to investigate the insight on 'TBC and biofuels (and blends) operation'. A total of 74 (seventy four) experimental results from 25 (twenty five) different studies were collated and reviewed for various biofuels (and blends) and ceramic coatings applications. In addition, another 7 (seven) literature were investigated to review the influences of injection parameters and preheating of the fuel in thermal barrier coated engines. The effects of partially coated combustion chambers and air inlet system were also reviewed in the current study. The aim of this study is to present a review on the effects of thermal barrier coatings on biofuels (and their blends) operated compression ignition (CI) engines in terms of their performance, combustion and exhaust gas emissions characteristics. The objectives of the study are: (i) collating the information related to the properties and types of materials used for thermal barrier coatings in IC engines (ii) reviewing the engine performance, combustion and exhaust gas emissions characteristics of the TBC engines running on various types of biofuels (and blends), (iii) investigating the effects of fuel injection parameters and preheating temperature on TBC engine performance, combustion and exhaust gas emissions characteristics operated with various types of biofuels (and blends), (iv) comparing the engine performance, combustion and exhaust emissions characteristics with and without thermal barrier coatings, and (v) identifying the areas for future R \& D activities on 'TBC and biofuels'. Results available in the literature were grouped in three different reference conditions: (i) comparison of uncoated engine (UD) with coated engine for fossil diesel fuel (CD) application only, (ii) uncoated engine fuelled with biofuel (UB) versus coated engine fuelled with biofuel (CB), and (iii) coated engine fuelled with biofuel (CB) verses uncoated engine fuelled with fossil diesel (UD). Section 1 presents the introduction and scope of the current review study. Types of coating materials and their properties associated with the IC engine components are discussed in section 2. Sections 3, 4 and 5 presents detailed review on engine performance, combustion and exhaust gas emissions characteristics of the TBC engines fuelled with various types of biofuels, blends and fossil diesel. Comparison of engine tests results are shown in tables and in figures. Section 6 addresses the conclusions of the study and areas for future R \& D study. 


\section{Thermal Barrier Coatings and Materials Properties}

Thermal barrier coating was first introduced in 1978 to assess the durability and performance parameters of the IC engine by decreasing the heat transfer from the combustion chamber [43]. Plasma spray technique is normally used to apply the TBC layers on the substrates (e.g. piston crown, cylinder liner, valves) due to its good splat structure with volume fracture of $10-20 \%$ voids and cracks [13]. The surface of the coated components can preserve high temperatures and additional energy available inside the combustion chamber could affect the mechanical power output, thermal efficiency, fuel consumption and exhaust gas emissions.

\subsection{Coating Layers and Type of Materials}

The TBC applied to the IC engines are comprised of two stage layers, known as primary and bond coating layers [22-24]. The primary ceramic layer acts as thermal insulation. The bond layer consists of metallic substances (Figure 2) which provides adherence between the metallic substrate and the primary layer. Bond layer prevents corrosion and oxidation on the surface of the metallic substrate [44,45]. Furthermore, bond layer is necessary as an intermediate element to prevent any possible damage due to the thermal shock between the substrate and the top coating layer. Table 1 shows requirement of the important properties of ceramic materials and how they affects the performance characteristics of the coatings. The thermal conductivity value is very crucial since the aim of coating is to reduce the heat rejection from the combustion chamber as maximum as possible [46]. Lower the thermal conductivity value of the coating material lower will be the heat rejection from the combustion chamber of the engine (Figure 3). Thermal expansion coefficient (TEC) is another important property to consider, if the thermal expansion coefficients of both layers (primary and bond) are close to each other, they would expand at a similar rate and the effect of thermal stress on coatings would be very minimum. The melting point and phase stability of the coating materials are also significant as the durability of the coatings has to be conserved after high temperature operations (Table 1). Popular ceramic coating materials, their advantages and disadvantages are collated in Table 2. The bond layer is made up of an intermetallic alloy which enhances the adhesion between the substrate and the upper layer. Aydin [21] reported that minor cracks on the ceramic coating were observed after 100 hours of operation (Figure 4) due to the absence of bond layer. Thermal expansion coefficients values of the bond layer must be lower than that of the coating layer and higher than metallic substrate [47-52]. Zirconates $\left(10^{-6} \mathrm{~K}^{-1}\right)$, garnets $\left(9.1 \times 10^{-6} \mathrm{~K}^{-1}\right)$, Yittria stabilized zirconia and forsterite $\left(11 \times 10^{-6} \mathrm{~K}^{-1}\right)$ have better TEC values than other materials (Table 2). Table 3 presents various types of TBC materials (both main and bond layer), layer thicknesses and substrate surfaces used by the researchers when the internal combustion engine was fuelled by various biofuels and/or blends. It was revealed that most studies used zirconium or similar materials $\left(\mathrm{ZrO}_{\mathrm{x}}\right)$ for primary layer and $\mathrm{NiCrAl}$ alloy for bond layer (Table 3). Primary layer thicknesses vary widely ranging from $150 \mu \mathrm{m}$ to $500 \mu \mathrm{m}$. On the other hand, thickness of the bond layer was between $0 \mu \mathrm{m}$ to $150 \mu \mathrm{m}$. The coatings were applied on cylinder head, piston crown, cylinder liners and valves. However, it was observed that the coatings on the cylinder head and piston crown were common in almost all studies (Table 3). 


\section{Coatings and Engine Performance Characteristics}

The effects of TBCs on biofuels (and biofuels blends) operated engine performance characteristics were reviewed and presented in Table 4 and in Figure 5. Performance parameters such as brake specific fuel consumption (bsfc), brake specific energy consumption (bsec), brake thermal efficiency, power output, coolant load and sound intensity were discussed under three different engine operation scenarios - (i) uncoated diesel to coated diesel (UD to CD), (ii) uncoated biofuel to coated biofuel (UB to CB), and (iii) uncoated diesel to coated biofuel (UD to CB) [Table 4, Figure 5].

\subsection{Brake Specific Fuel Consumption}

In general, the brake specific fuel consumption (bsfc) were increased in unmodified engines, when fuelled with biofuels (or blends) as compared to fossil diesel operation [4-6,53-57]. On the other hand, significant improvements in the bsfc were reported in the literature when TBC technique was implemented (Table 4, Figure 5). Reduction on bsfc of up to $13.4 \%$ was reported for UB versus CB application [28] (Table 4). Higher temperature in the combustion chamber helped to shorten the ignition delay period and burn biofuel more effectively than in uncoated engine, hence lower fuel is needed to produce the same output power. Table 4 shows the improvements of bsfc values under various scenarios. Furthermore, few studies reported that the bsfc of the coated biofuel application was even lower than the uncoated diesel (UD) application (Table 4, Figure 5). In contrast, increase in the bsfc was also reported in biofuels operated coated engine [24]. Use of spark ignition engine might have caused this unusual characteristics. Overall, biofuels (and blends) used in coated engines produced lower brake specific fuel consumption of between $3 \%$ and $13.4 \%$, when compared to uncoated engines. Highest bsfc reduction was reported by Reddy [28]; they used neat mohr oil biofuel and partially stabilised zirconium as coating material.

\subsection{Brake Specific Energy Consumption}

Properties of biofuels (and blends) e.g. density are different than fossil diesel. Brake Specific Energy Consumption (BSEC) is another important parameter to assess the specific energy consumption of biofuels and then compare them with that of fossil diesel [58]. Table 4 illustrated that in almost all cases the bsec values were reduced when coatings were applied in biofuels (or blends) operated engines (ie. UB verses CB scenarios). Enhanced temperature inside the combustion chamber led to better combustion of biofuels. As a result of TBC modifications, the highest reductions on bsec were reported to be $7.4 \%$ for diesel [23] and $15.4 \%$ for biofuel [17]. Furthermore, literature showed that other engine modifications like changing injection timing, injector opening pressure and preheating temperature of biofuels could further reduce the specific energy consumptions in both coated and uncoated engines (Table 5). The cetane number of the biofuel plays an important role on fuel injection parameters adjustment. Biofuels having lower cetane number than fossil diesel prevalently modified by advancing the injection timing. Up to $4.4 \%$ and $5.6 \%$ reductions on bsec were observed when injection timing was advanced by $3^{\circ}$ and $6^{\circ} \mathrm{CA}$ respectively [36] (Table 5). 


\subsection{Brake Thermal Efficiency}

The brake Thermal efficiency (BTE) can be explained as the percentage of chemical energy contained in the fuel converted into useful mechanical work. Use of thermal barrier in the combustion chamber could capture more mechanical energy. In addition to TBC, additional oxygen content in the biofuel might also help to achieve higher thermal efficiency [23]. Deviations in the brake thermal efficiencies due to the thermal barriers are reviewed and presented in Table 4. Not surprisingly, for both UD to CD and UB to CB scenarios, improved BTE values were reported in the range of $0 \%$ to $6.7 \%$ and $2.2 \%$ to $18 \%$ respectively. Furthermore, in the case of UD to CB scenario, relatively higher improvement on BTE of $6.3 \%$ [31], and 4.9\% [34] were reported. In contrast, 4.9\% [27] and 3.7\% [26] decrease in the BTE values were also reported when switched from UD to CB operation. It was thought that biofuel types and quality of coatings might have caused these unexpected results. Interestingly, one study reported a $10.7 \%$ increase in the BTE value for UD to CB scenario, optimisation of the injection timing and application of TBC both jointly contributed to achieve increased BTE value [36]. Effects of fuel injection parameters and preheating temperature on BTE values in both coated and uncoated engines were also collated (Table 6). It was found that, in general, higher injection pressure and preheated fuels gave higher BTE values in both uncoated and coated engines. This can be attributed to the improved combustion characteristics as a result of upgraded spray characteristics of the fuel [59]. In addition, advancing the injection timing also gave improved BTE vales in both types of engines (Table 6). However, the relationship between the injection timing and BTE values are not liner; maximum BTE value can be obtained at optimum injection timing. The optimum injection timing and injection opening pressure would also depend on the physicochemical properties of the fuel and other modifications of the engine. For example, the optimum injection timing in coated engine was reported to be $30^{\circ} \mathrm{bTDC}$ when rice bran oil was used in the engine [33]. On the other hand, Reddy et al stated the optimum injection timing as $28.5^{\circ} \mathrm{bTDC}$ for coated engine operated with mohr oil [28]. This was due to the different ignition delays and combustion duration characteristics of the fuels.

\subsection{Engine Power}

Generally, due to the lower heating values and higher kinematic viscosities, use of renewable biofuels causes reductions in the power output of the engine [4,7,60-63]. The current review study revealed that TBC method is a promising solution to prevent the engine power loss when biofuels are used instead of fossil diesel ([31,32], Table 4, Figure 5). Literature shows that up to $9.2 \%$ improvement in the engine power can be achieved for UD to CD tests scenario. Whereas, the power and torque output from biofuels powered coated engines (CB) were reported to be $7.8 \%$ and $4.6 \%$ higher than the uncoated engines (UB) using same biofuels([31], Table 4, Figure 6). However, on the other hand, decrease in the engine power output was also reported (Table 4), use of poor quality biofuels (or blends) in the coated engines might have caused this characteristics. Upgradation of the fuels properties, and optimisation of preheating temperature and injection parameters would offset the engine power loss. Poor performance of the coatings could also lead to loss in the engine power output. 


\subsection{Coolant Load and Sound Intensity}

Coolant load (CL) and sound intensity (SI) are two other parameters which are also affected by the use thermal barrier coatings appled inside the combustion chamber of the engine (Figure 7). As the insulated components (coatings) in the combustion chamber decreases the heat transfer from working fluid (air and fuel mixture) to the coolant fluid; hence, the cooling loads (CL) of the engine system are expected to be reduced. Table 4 shows changes in the cooling loads when coating was applied to the engine. Reduction of up to $19 \%$ on the CL was reported by Srikanth [36] for UB to CB application. In another study, 18.2\% reduction in CL was mentioned by Reddy [28] in UD to CB operation scenario. Decreased cooling load have multiple advantages, some of them are: (i) would decrease the weight of the engine, and (ii) would reduce the cost of the cooling system. When compared to uncoated engines, sound intensity were decreased significantly in coated engines (Table 4). Coated engines could provide up to $11.8 \%$ silent operation than conventional diesel engines when fuelled with renewable biofuels (Figure 7). It was believed that smooth combustion of the fuels in TBC engines cased this behaviour.

\section{Coatings and Combustion Characteristics}

Application of the thermal barrier coatings affects the combustion characteristics of the engine. The various combustion parameters discussed in this section are: peak in-cylinder pressure, heat release rate, exhaust gas temperature and volumetric efficiency. The deviations in combustion characteristics were reviewed and presented in table 7 and in figure 7, the results were grouped in three main scenarios i.e. UD to $\mathrm{CD}$, UB to $\mathrm{CB}$ and $\mathrm{UD}$ to $\mathrm{CB}$.

\subsection{Peak in-cylinder Pressure}

Most studies reported increased in-cylinder pressures when biofuels (and/or biofuels blends) were used in coated engines as compared to uncoated engines. This can be explained by gas kinetic theory. The mean square temperature of gas molecules increases in coated engines as a result of thermal barrier [24]. The higher the gas temperature higher would be the gas pressure. Janardhan [14] reported that maximum peak pressure was increased by 16.3 bars (33.5\%) in the case of UB to CB application. In the case of UD to CB scenario, most studies reported increased peak in-cylinder pressures (Table 7). However, few studies reported decreased in-cylinder pressures by 2 bars [26] and 0.7 bars [34] for UD to CB application. It was revealed that the partial coating (only piston crown coating) caused this [26] unexpected characteristic, as engine cooling is mainly affected by the changes in the cylinder liner and cylinder head.

Table 8 demonstrated the effects of injection timing, injector opening pressure and fuel temperature on peak in-cylinder pressure, maximum rate of in-cylinder pressure rise and crank angle position at peak in-cylinder pressure. Most studies reported that the peak incylinder pressure can be increased by changing the injection timing and increasing the injector opening pressure (IOP) in both coated and uncoated engines (Table 8). For example, 
Janardhan et al. reported an increase in the peak in-cylinder pressure by 2 bar when the injection timing in coated engine was advanced by $5^{\circ} \mathrm{CA}$ [14]. The engine was operated with jatropha oil biodiesel and the IOP was set at 190 bar. The authors reported that, the peak incylinder pressure was further increased by 3 bar when the IOP was increased form 190 bar to 270 bar [14]. Similarly, in tobacco seed oil biodiesel fuelled coated engine, Rao et al. observed 13.1 bar increase in the peak in-cylinder pressure when the injection timing was advanced by $3^{\circ} \mathrm{CA}$ [29]. Advancing the injecting timing allowed extra delay time which helped in better mixing of biofuels with intake air. Furthermore, most biofuels have higher viscosity values than fossil diesel. Higher injection pressure produced smaller droplets sizes and better spray characteristics.

In general, maximum rate of in-cylinder pressure rise (MRICPR) of fossil diesel is typically higher than biofuels when unmodified engines are used. Low cetane number and high viscosity of biofuels (and their blends) caused this characteristic. However, improvement in the MRICPR values were observed in coated engines (Table 8). Srikanth et al. [36] reported that MRICPR was increased by $0.1 \mathrm{bar} / \mathrm{deg}$ in coated engine when operated with cotton seed oil biodiesel as compared to uncoated engine operated with the same biofuel. Improvement on MRICPR by 0.9 bar/deg was also observed by Rao et al. [29] using tobacco seed oil biodiesel in coated engine. Reddy et al [28] reported that the MRICPR was increased by 1.0 bar/deg and $0.7 \mathrm{bar} / \mathrm{deg}$ when operated with mohr oil and for mhor oil biodiesel respectively. A substantial increase in MRICPR by 2.2 bar/deg was observed by Krishna et al. [58] when jatropha oil was used in the coated engine. The MRICPR was increased by $1.0 \mathrm{bar} / \mathrm{deg}$ and $0.9 \mathrm{bar} / \mathrm{deg}$ for rice brawn oil [33] for jatropha oil biodiesel operation [14]. Combined effects of fuel properties, preheating temperature, engine specification and injection parameters caused wide variations in the MRICPR values. It was revealed that optimising the injection parameters and preheating temperature could further improve the MRICPR values in TBC engines (Table 8). In addition, these parameters also affected the angle or time of occurrences of peak in-cylinder pressures. Krishna et al. reported that in the case of rice brawn oil operated TBC engine, the time of peak in-cylinder pressure was advanced by $2^{\circ} \mathrm{CA}$ (approaching to TDC) when the injection timing was changed from $27^{\circ} \mathrm{bTDC}$ to $30^{\circ} \mathrm{bTDC}$ [33]. The authors also noticed further advancement by $1^{\circ} \mathrm{CA}$ when the injection pressure was increased from 190 bar to 270 bar (without changing the injection timing (i.e. $27^{\circ} \mathrm{bTDC}$ )) [33]. Another study observed that in both coated and uncoated engines, the time of occurrence of peak in-cylinder pressure was changed by $1^{\circ} \mathrm{CA}$ (approaching to TDC) when the temperature of tobacco seed oil biodiesel was preheated to $60^{\circ} \mathrm{C}$ ([29], Table 8).

\subsection{Exhaust Gas Temperature}

Exhaust gas temperature (EGT) is directly related to the combustion temperature. Therefore, EGT is expected to rise in TBC engines. In addition, high combustion temperatures could also affect the composition and quantity of the exhaust gases. Up to $22 \%$ increase in EGT was observed (Table 7) for UD to CD scenario. However, in the case of biofuel (and blends) coated engines, a mixed picture was found with up to $10 \%$ reduction and up to $14 \%$ increase when compared to uncoated biofuel operation (Table 7). However, in general, EGT was 
increased due to the application of thermal barrier. High EGT could be achieved in turbocharged engine using the exhaust gas recirculation technique. Hence, the application of TBC in turbocharged engine could help to improve the overall performance of the IC engine even better [64].

\subsection{Heat Release Rate}

Heat Release Rate (HRR) is another combustion parameter which could be affected due to the application of the thermal barrier. Table 7 shows deviations in the HRR when coatings were applied. In the case of coated biofuel operation, Aydin [20], MohamedMusthafa [17], Taymaz [16] and Prasath [34] reported that the HRR were decreased by 20\%, 3\%, 19\% and $27 \%$ respectively when compared with the uncoated engines. In contrast, Prabhahar [26] and Rajan [27] found that HRR were increased by 5\% and $13.8 \%$ when coatings were applied. It was discovered that coating piston crowns only led to the increased HRR values (Table 3 ).

\subsection{Volumetric Efficiency}

Volumetric efficiency (VE) is the ability of the engine to breath. It is a ratio of the actual air intake to the theoretically possible maximum air intake. Theoretical maximum intake is the amount of air contained in the cylinders at the manifold temperature [65]. MohamedMusthafa [17] indicated that there is a link between the volumetric efficiency and the thickness of the coating. They reported that VE was decreased by $5.5 \%$ and $7.7 \%$ respectively for the UD to $\mathrm{CD}$ and UD to $\mathrm{CB}$ applications for coating thickness lower than the $250 \mu \mathrm{m}$,. On the otherhand, in the case of higher coating thicknesses (about $500 \mu \mathrm{m}$ ), relatively higher reductions of $8.2 \%$ for UD to CD and $11.8 \%$ for UD to CB applications were observed ([36], Table 7, Figure 7)). This phenomenon can be linked to the changes in the air density. As the thickness of the coating increases, the average temperature inside the cylinder increases. Air expands at higher temperatures; and as a result, number of the air molecules entering the cylinder will be lower as compared to uncoated condition. Nevertheless, modified injection timing [28] and use of turbocharged engine [66] could help to compensate the deterioration of the volumetric efficiency in coated engines.

\section{Coatings and Exhaust Gas Emissions}

Effects of TBCs on exhaust gas emissions $\left(\mathrm{CO}, \mathrm{CO}_{2}, \mathrm{HC}, \mathrm{NO}_{\mathrm{x}}\right.$ and smoke intensity) were collated (Table 9, Figure 8) and discussed. Unlike engine performance and combustion characteristics, exhaust gas emission characteristics were also reviewed under three different scenarios - UD to CD, UB to $\mathrm{CB}$ and UD to $\mathrm{CB}$.

\subsection{CO Emission}

Various parameters such as ambient conditions, engine speed and load, air-fuel ratio, geometry of the combustion chamber and piston, atomisation, type of injection, injector geometry, injection pressure and timing, heat rejection via coolant, and fuel properties affects the concentration of gas components in the exhaust gas. Emission of $\mathrm{CO}$ gas is primarily dependent on the amount of oxygen content in the air-fuel mixture. Insufficient oxygen 
content during the combustion process generally lead to higher $\mathrm{CO}$ gas emission $[4,67,68]$. Guru et al. [67] reported that in addition to $\mathrm{HC}$ gas, concentration of $\mathrm{CO}$ gas also represent the efficiency of combustion i.e. conversion of chemical energy into mechanical energy. Various authors reported that use of biofuels in unmodified engines could reduce the $\mathrm{CO}$ gas emissions due to the higher oxygen content in the biofuels (and in blends) [53-56,69]. Literature shows that further reduction in the $\mathrm{CO}$ emission could be achieved by $\mathrm{TBC}$ application (Table 9) in all three comparison scenarios (Table 9). Use of $\mathrm{ZrO}_{2}, \mathrm{ZrO}_{3}, \mathrm{TiO}_{2}$ and Mo coating materials helped to achieve better $\mathrm{CO}$ gas reduction than other types (Tables 3 and 9). Iscan [22] and Aydin [21] reported that up to $81.3 \%$ and $93.8 \%$ reduction in the CO gas emissions were achieved for fossil diesel and biofuel respectively when coatings were applied in the combustion chamber. CO gas emissions of coated and uncoated engines were almost comparable at low and medium engine speeds; however, at high speed operation, significant decrease in the CO emission was reported when coated engine was used [21,22]. Furthermore, Kumar [23] reported that for biofuel operation, concentration of CO increased with the increase in engine power output.

\section{2. $\mathrm{CO}_{2}$ Emission}

The lifecycle $\mathrm{CO}_{2}$ emissions can be reduced significantly by replacing fossil diesel with the renewable biofuels and/or blends [54,60]. Biofuels are considered as carbon neutral due to the fact that the $\mathrm{CO}_{2}$ gases emitted from biofuels combustion could be used to grow biomass [70-73]. However, the intensity of tailpipe $\mathrm{CO}$ and $\mathrm{CO}_{2}$ gases depends on the air-fuel ratio and other parameters. Aydin [21] reported that, both engine speed and thermal barrier coatings have huge impact on the $\mathrm{CO}_{2}$ emissions. The author found that $\mathrm{CO}_{2}$ emission of fossil diesel was decreased by about $19.4 \%$ at low and medium engine speed operation; on the other hand, in case of high engine speed operation, $\mathrm{CO}_{2}$ emission was increased by about $29.2 \%$. For coated biofuel operation, $\mathrm{CO}_{2}$ emissions of CSO35 (35\% cottonseed oil biodiesel, $65 \%$ diesel) and SFO35 (35\% sunflower oil biodiesel, 65\% diesel) were reduced by $11.1 \%$ and $2.8 \%$ respectively at low and medium range engine speeds; however, at high speed, they were increased by $20 \%$ and $23 \%$ respectively [21]. It can be concluded that in coated engines, $\mathrm{CO}_{2}$ emission was decreased at low to medium speed operation; however, at high speed and high load operation, $\mathrm{CO}_{2}$ emission could increase.

\subsection{HC Emission}

$\mathrm{HC}$ gas is not toxic by itself, they react with other pollutants in the atmosphere. Emission of $\mathrm{HC}$ gases are caused by incomplete combustion of fuels [60]. Literature reported that the TBC engines emitted significantly lower HC emissions in all three scenarios when compared to uncoated engines (Table 9). Higher lean flammability and reduced distance for quenching due to the thermal barrier caused this [12,24]. Up to $92.5 \%$ reduction in $\mathrm{HC}$ gas emission was reported when biofuel was used in coated engine instead of uncoated engine [26].

\section{4. $\mathrm{NO}_{\mathrm{x}}$ Emission}

Emission of $\mathrm{NO}_{\mathrm{x}}$ gases depends on mainly combustion temperature and air-fuel ratio. When the combustion temperature exceeds about $1800 \mathrm{~K}$, nitrogen and oxygen molecules combines and produces nitrogen oxides [74]. Emission of $\mathrm{NO}_{\mathrm{x}}$ gases affects environment and human health. Human lungs are affected by $\mathrm{NO}_{\mathrm{x}}$ gases; they react with the water vapour and form nitric acid inside the lungs which causes respiratory diseases [2]. Table 9 shows that almost all studies reported increased $\mathrm{NO}_{\mathrm{x}}$ emissions regardless of type of fuels used, coating materials and coating thicknesses. For UB to $\mathrm{CB}$ scenario, $\mathrm{NO}_{\mathrm{x}}$ emissions were increased in the range of between $4 \%$ and $62.9 \%$. The small increase $(4 \%)$ in $\mathrm{NO}_{\mathrm{x}}$ emission was due to the partial coating (only piston crown with $500 \mu \mathrm{m}$ was coated) [26]. 


\subsubsection{Reduction of $\mathrm{NO}_{x}$ Emission}

Thermal barrier resulted increased interaction between nitrogen and oxygen at high combustion temperature and hence $\mathrm{NO}_{\mathrm{x}}$ emissions were increased [17]. Literature reported that injection timing can also affect $\mathrm{NO}_{\mathrm{x}}$ gas emissions, Kumar [23] and Alkidas [75] found that $\mathrm{NO}_{\mathrm{x}}$ emission could be decreased by decreasing the ignition delay (by advancing the fuel injection timing). Buyukkaya et al [76] reported that combined TBC injection timing modifications resulted $2.44 \%$ reduction in $\mathrm{NO}_{\mathrm{x}}$ emission at low loads and low-speed engine operation. They used $150 \mu \mathrm{m}$ thick $\mathrm{NiCrAl}$ material as bond layer in the pistons; on top of the bond layer, $\mathrm{MgZrO}_{3}$ was coated with the thickness of $350 \mu \mathrm{m}$. In addition to pistons, cylinder head and valves were also coated with $\mathrm{CaZrO}_{3}$ material. The compression ratio was kept constant by removing the substrates material equal to that of combined thickness of both bond and main coatings (ie. $500 \mu \mathrm{m}$ ) [76]. However, they also reported about $9 \%$ higher $\mathrm{NO}_{\mathrm{x}}$ emission at high load and low-speed operation than uncoated engine. Sathiyagnanam et. al. [35] reported up to $46.5 \%$ decrease in the $\mathrm{NO}_{\mathrm{x}}$ emission for UD to CD scenario. They used $\mathrm{Al}_{2} \mathrm{O}_{3}$ as coating material and diisopropyl ether as an additive with fossil diesel. It was thought that the use of additive and $\mathrm{Al}_{2} \mathrm{O}_{3}$ as coating material might have caused low $\mathrm{NO}_{\mathrm{x}}$ emission. Hazar and Ozturk [18] used $\mathrm{Al}_{2} \mathrm{O}_{3}$ as coating material and reported $14.7 \%$ increase in the $\mathrm{NO}_{\mathrm{x}}$ emission; however, this value was lower than the average increase $(30.5 \%)$ in NOx emissions reported by other studies (Table 9).

Table 10 shows the effects on injection parameters and preheating of the fuel on $\mathrm{NO}_{\mathrm{x}}$ emissions. Literature reported that in coated engines, $\mathrm{NO}_{\mathrm{x}}$ emissions could be decreased by advancing the injection timing in coated engines (Table 10). Srikanth et al. [36] found out that up to $7 \%$ reduction on $\mathrm{NO}_{\mathrm{x}}$ emission was possible in cotton seed oil biodiesel powered coated engine when the injection timing was advanced by $3^{\circ} \mathrm{CA}$. The $\mathrm{NO}_{\mathrm{x}}$ reduction by advancing the injection timing was linked to decreased gas mixture temperature [36]. Similar reductions on $\mathrm{NO}_{\mathrm{x}}$ emissions in coated engines were also reported by other studies: (i) 50 ppm (4.2\%) reduction for tobacco seed oil biodiesel operation when injection timing was advanced by $3^{\circ}$ bTDC [29], and (ii) $40 \mathrm{ppm}(3.9 \%)$ reduction for mohr oil operation when injection timing was advanced by $1.5^{\circ} \mathrm{bTDC}$ [28]. In addition, literature showed that increased injector opening pressure and preheating the fuel helped to achieve lower $\mathrm{NO}_{\mathrm{x}}$ emissions (Table 10). It was revealed that the NOx reductions in coated engines were only possible to a certain extent via various additional modifications; however, very few studies were able to balance the NOx emissions before and after the thermal barrier coatings were applied (Table 10).

\subsubsection{Selective Catalytic Reduction}

In addition to injection parameters modifications, use of selective catalytic reduction (SCR) could be implemented to further reduce the NOx emissions in coated engines. The SCR system can be installed easily in the exhaust system as an after treatment component. In SCR technique, ammonia $\left(\mathrm{NH}_{3}\right)$ is injected into the exhaust gas which converts nitrogen oxides into nitrogen, water and tiny amounts of carbon dioxide [77]. Xiaoyan et al. [78] reported that the use of SCR treatment reduced the $\mathrm{NO}_{\mathrm{x}}$ emissions by $73 \%$ when the engine was operated 
with biodiesel-ethanol-diesel blend. In another study, Vallinayagam et al. [79] managed to reduce the $\mathrm{NO}_{\mathrm{x}}$ emissions of pine-fossil diesel blend fuelled engine by $40 \%$ when SCR system was used. The SCR after treatment technique seems very promising for reducing the $\mathrm{NO}_{\mathrm{x}}$ emissions in biofuels operated TBC engines.

\subsection{Smoke and Particulate Matter}

Generally, there are big concerns on high level particulate matter (PM) emissions from compression ignition engines. Researchers stated considerable decreases in PM and soot emissions when oxygenated fuels such as biofuels were used in the engine [4,5,80,81]. The concentration of oxygen content in the chemical structure of biofuels is an important parameter which affects the darkness of the exhaust smoke by filling the sudden local oxygen vacancies [17]. This phenomenon results in a significant reduction on biofuels smoke opacity when compared with the same for fossil diesel. Literature shows that thermal barrier coatings contributed to further reductions in the smoke intensity and particulate matter emission. Table 9 shows variations in PM and smoke opacity emissions when coatings were applied to engines. As an example, a reduction of up to $55.6 \%$ in smoke opacity can be achieved by coating the engine [21]. In coated engines, PM emissions were decreased considerably than standard engines both at low and high engine speeds operation (Table 9). At high engine loads, approximately 40\% lower PM emissions were observed than standard engine [76]. Furthermore, turbocharged engine showed relatively higher PM and smoke reductions due to the increased air (or oxygen) content available for combustion in each cycle.

Furthermore, the smoke emission characteristics were also affected by the injection parameters and fuel preheating (Table 11). Reduction on smoke intensity were observed by advancing the injection timing and/or increasing the injector opening pressure. This can be attributed to the improved spray characteristics and better mixing of the fuel-air inside the combustion chamber. Preheating the fuel reduces the viscosity and density values of the fuel, and ultimately will lead to reduced smoke emissions (i.e. improved combustion) [28]. Srikanth et al. [36] obtained up to $70 \%$ reduction on smoke emissions in cotton seed oil biodiesel powered coated engine when all three parameters were optimised (i.e. advancing injection timing, increasing injection pressure and preheating the fuel).

\section{Conclusions and Future R\&D Areas}

In this study, effects of thermal barrier coatings on the compression ignition engine performance, combustion, and exhaust gas emissions characteristics were investigated when biofuels (and blends) were used instead of fossil diesel. The literature findings were discussed in three main categories: UD to $\mathrm{CD}, \mathrm{UB}$ to $\mathrm{CB}$ and UD to $\mathrm{CB}$ applications. The effects of injection timing, injector opening pressure and preheating condition of the fuel in $\mathrm{TBC}$ engines were also reviewed. A total of 74 case studies from 28 literature were reviewed and presented. To help the research community and relevant industry, the engine characteristics results were grouped and tabulated based on various reference scenarios. The main findings of the study are highlighted below: 
(i) Most researchers used ceramic based materials for coatings due to their higher endurance level against higher temperature and low thermal conductivity values. Zirconia is one of the most frequently used candidate material for thermal barrier coatings. Selection of physical thickness, material properties such as thermal expansion and conductivity are very crucial for durability and performance of the coating layer. Thermal barrier coatings were applied on cylinder liner, piston crown and valves. Application of bond coat layer is very important to create strong adhesion between the substrate and the primary layer. Moreover, bond layer reduces the risk of thermal fatigue failures. Application of thick $(0.5 \mu \mathrm{m}$ or above $)$ coatings could produce negative effect on the volumetric efficiency and lubrication of piston-cylinder liner. In addition, this can also lead to reduced adhesion of the coating with the substrate.

(ii) Coated engines could achieve around 11\% higher temperatures inside the combustion chamber with respect to the uncoated engines. Increased combustion temperature helps to ignite the fuel faster. Some of the important combustion characteristics in the TBC engines are: reduced ignition delay, longer combustion duration, less heat release rate, increased maximum rate of in-cylinder pressure rise, multi-fuels flexibility, better mixing and faster vaporisation of the fuels, easy start-up of the engine and reduced noise and knocking during the combustion. These characteristics would help to burn relatively high viscosity and low cetane number renewable biofuels more efficiently when compared to combustion of the same fuel in standard uncoated engines.

(iii) Generally, performance of a CI engine decreases when biofuels are used instead of standard fossil diesel in unmodified engines. However, application of thermal barrier coatings in biofuels (or blends) operated engines would lead to achieve comparable performance similar to fossil diesel. Improvement in power output, torque, BSFC, BSEC and BTE were observed by the researchers when biofuels (and blends) were used in TBC engines as compared to uncoated engines. Increase of up to $7.8 \%$ in power output and $10.7 \%$ in brake thermal efficiency were reported by the authors when coatings were applied. Up to about $13.4 \%$ reduction in the brake specific fuel consumption and $15.4 \%$ reduction in the brake specific energy consumption were also reported in the literature.

(iv) Only piston crown coating is not sufficient to achieve better or comparable performance with reference to uncoated condition as main heat transfers takes place between the combustion chamber (cylinder liners) and cooling jacket system. Most literature reported that coating of the cylinder liner reduces the HRR. Furthermore, increased peak in-cylinder pressures and exhaust gas temperatures were also reported. However, increased HRR in coated engines were also reported in the literature.

(v) Due to the better combustion characteristics, coated engines work smother. On average, biofuels (and blends) operated coated engines gave reduced $\mathrm{CO}, \mathrm{HC}$ and smoke opacity emissions by about $20 \%, 50 \%$ and $25 \%$ respectively when compared to uncoated engines,. In coated engines, emission of $\mathrm{CO}_{2}$ gas decreased at low and medium speed operation. However, at high speed and high load operation, higher $\mathrm{CO}_{2}$ emission was reported when compared to uncoated engines. The $\mathrm{NO}_{\mathrm{x}}$ gas emission was increased by about $30 \%$ on average, when biofuels were used in the coated engines. As $\mathrm{NO}_{\mathrm{x}}$ emissions are likely to 
increase in the TBC engines, use of selective catalytic reduction is highly recommended as an after-treatment method. Additives in the biofuel could also help to reduce the $\mathrm{NO}_{\mathrm{x}}$ gas emission in the coated engines.

(vi) Optimisation of the injection parameters (injection timing and pressure) and preheating of the fuel gave improved performance and combustion characteristics in TBC engines. Up to $4.5 \%$ increase in the brake thermal efficiency was achieved by advancing injection timing. Also, increased injector opening pressure resulted up to $2 \%$ increase in the brake thermal efficiency. The $\mathrm{NO}_{\mathrm{x}}$ emissions of the biofuel operated $\mathrm{TBC}$ engine could be reduced significantly by optimising the injection parameters and preheating temperature of the fuel.

(vii) Use of turbocharger would further improve the performance, smoke and PM emission characteristics of the coated engines. Increased combustion temperature could deteriorate the lubricant properties, extra attention would be needed on the lubricating oil properties. Thermal barrier coatings reduce the thermal stress on the coated components, which eventually will help to increase the lifetime and decrease the possibility of the thermal fatigue failures of the components.

Following R\&D topics are recommended as future study:

- Long term durability study of the coated engines running with various types of biofuels and blends. Investigation on the frictional power losses using various types of lubricants is an important area for future study.

- Investigating the effects of coating thicknesses and type of coating materials on the engine performance and emission characteristics. Optimisation of the combustion chamber geometry for thermal barrier coated engines is another topic for future study.

- Detailed experimental study on the optimum injection timing and the injection pressures for biofuels (or blends) application in the coated engines. Effects of various combustion and injection types (HCCI, dual fuelled, DI, IDI, dual injection, variable compression) on biofuels operated coated engines is another important R \& D topic.

- Effects of new low load cooling system on engine performance and emission characteristics. Combined investigation on the optimisation of cooling fluid temperature and thermal barrier coatings is another important topic for future work.

\section{Acknowledgment}

This work was supported by the School of Engineering and Applied Science (Aston University, UK) under the PhD studentship programme for new academics. 


\section{References}

[1] The World Bank, Fossil fuel energy consumption, (2017). http://databank.worldbank.org/data/reports.aspx?source=2\&series=EG.USE.COMM.F O.ZS\&country= (accessed April 23, 2017).

[2] A.C. Lloyd, T.A. Cackette, Diesel engines: environmental impact and control, J. Air Waste Manage. Assoc. 51 (2001) 809-847.

[3] M. Gumus, C. Sayin, M. Canakci, The impact of fuel injection pressure on the exhaust emissions of a direct injection diesel engine fueled with biodiesel--diesel fuel blends, Fuel. 95 (2012) 486-494.

[4] R. Behçet, Performance and emission study of waste anchovy fish biodiesel in a diesel engine, Fuel Process. Technol. 92 (2011) 1187-1194.

[5] C. Öner, S. Altun, Biodiesel production from inedible animal tallow and an experimental investigation of its use as alternative fuel in a direct injection diesel engine, Appl. Energy. 86 (2009) 2114-2120.

[6] C.-Y. Lin, R.-J. Li, Engine performance and emission characteristics of marine fish-oil biodiesel produced from the discarded parts of marine fish, Fuel Process. Technol. 90 (2009) 883-888.

[7] S. Godiganur, C.S. Murthy, R.P. Reddy, Performance and emission characteristics of a Kirloskar HA394 diesel engine operated on fish oil methyl esters, Renew. Energy. 35 (2010) 355-359.

[8] G. Sakthivel, G. Nagarajan, M. Ilangkumaran, A.B. Gaikwad, Comparative analysis of performance, emission and combustion parameters of diesel engine fuelled with ethyl ester of fish oil and its diesel blends, Fuel. 132 (2014) 116-124.

[9] A.K. Hossain, P.A. Davies, Plant oils as fuels for compression ignition engines: A technical review and life-cycle analysis, Renew. Energy. 35 (2010) 1-13. doi:10.1016/j.renene.2009.05.009.

[10] T. Ganapathy, R.P. Gakkhar, K. Murugesan, Influence of injection timing on performance, combustion and emission characteristics of Jatropha biodiesel engine, Appl. Energy. 88 (2011) 4376-4386.

[11] A.K. Hossain, P.A. Davies, Performance, emission and combustion characteristics of an indirect injection (IDI) multi-cylinder compression ignition (CI) engine operating on neat jatropha and karanj oils preheated by jacket water, Biomass and Bioenergy. 46 (2012) 332-342.

[12] S.H. Chan, K.A. Khor, The effect of thermal barrier coated piston crown on engine characteristics, J. Mater. Eng. Perform. 9 (2000) 103-109.

[13] H. Samadi, T.W. Coyle, Alternative thermal barrier coatings for diesel engines, in: 5th Congr. Iran Ceram. Soc. Iran. Ceram. Soc., 2009: pp. 1-8.

[14] N. Janardhan, M.V.S. Murali Krishna, P. Ushasri, P.V.K. Murthy, Exhaust emissions and combustion characteristics of jatropha oil in crude form and biodiesel of low heat rejection diesel engine, Int. J. Soft Comput. Eng. 3 (2013) 91-95.

[15] S.I. Patel, D.C. Gosai, V.Y. Gajjar, Performance and exhaust emission analysis of thermal barrier coated diesel engine using rice bran oil biodiesel, Int. J. Eng. Adv. Technol. 2 (2013) 2249-8958.

[16] I. Taymaz, K. Cakir, M. Gur, A. Mimaroglu, Experimental investigation of heat losses in a ceramic coated diesel engine, Surf. Coatings Technol. 169 (2003) 168-170.

[17] M. MohamedMusthafa, S.P. Sivapirakasam, M. Udayakumar, Comparative studies on fly ash coated low heat rejection diesel engine on performance and emission characteristics fueled by rice bran and pongamia methyl ester and their blend with diesel, Energy. 36 (2011) 2343-2351. 
[18] H. Hazar, U. Ozturk, The effects of Al 2 O 3--TiO 2 coating in a diesel engine on performance and emission of corn oil methyl ester, Renew. Energy. 35 (2010) 22112216.

[19] A. Parlak, The effect of heat transfer on performance of the Diesel cycle and exergy of the exhaust gas stream in a LHR Diesel engine at the optimum injection timing, Energy Convers. Manag. 46 (2005) 167-179.

[20] S. Aydin, C. Sayin, Impact of thermal barrier coating application on the combustion, performance and emissions of a diesel engine fueled with waste cooking oil biodiesel-diesel blends, Fuel. 136 (2014) 334-340.

[21] H. Aydin, Combined effects of thermal barrier coating and blending with diesel fuel on usability of vegetable oils in diesel engines, Appl. Therm. Eng. 51 (2013) 623-629.

[22] B. ISCAN, Application of ceramic coating for improving the usage of cottonseed oil in a diesel engine, J. Energy Inst. 89 (2016) 150-157.

[23] D.V. Kumar, P.R. Kumar, M.S. Kumari, Prediction of performance and emissions of a biodiesel fueled Lanthanum Zirconate coated direct injection diesel engine using artificial neural networks, Procedia Eng. 64 (2013) 993-1002.

[24] N. Mittal, R.L. Athony, R. Bansal, C.R. Kumar, Study of performance and emission characteristics of a partially coated LHR SI engine blended with n-butanol and gasoline, Alexandria Eng. J. 52 (2013) 285-293.

[25] E. Palaniswamy, N. Manoharan, Ceramic coated combustion chamber for improving IC engine performance, Int. J. Des. Manuf. Technol. 2 (2008).

[26] M. Prabhahar, K. Rajan, Performance and combustion characteristics of a diesel engine with titanium oxide coated piston using Pongamia methyl ester, J. Mech. Sci. Technol. 27 (2013) 1519-1526.

[27] K. Rajan, K.R.S. Kumar, Combustion and emission characteristics of a biodiesel fuelled diesel engine with the effect of thermal barrier coated internal jet piston, in: Sustain. Energy Intell. Syst. (SEISCON 2011), Int. Conf., 2011: pp. 184-189.

[28] T.R. Reddy, M.V.S.M. Krishna, C.K. Reddy, P.V.K. Murthy, Comparative performance of ceramic coated diesel engine with mohr oil in crude and biodiesel form, Int. J. Eng. Adv. Technol. 2 (2012) 588-596.

[29] N.V. Rao, M.V.S.M. Krishna, P.V.K. Murthy, Comparative studies on exhaust emissions and combustion characteristics of ceramic coated diesel engine with tobacco seed oil based biodiesel, Int. J. Adv. Sci. Tech. Res. 3 (2013) 334-349.

[30] A. Parlak, H. Yasar, O. Eldogan, The effect of thermal barrier coating on a turbocharged Diesel engine performance and exergy potential of the exhaust gas, Energy Convers. Manag. 46 (2005) 489-499.

[31] C. Hasimuglu, M. Ciniviz, I. Özsert, Y. Içingür, A. Parlak, M.S. Salman, Performance characteristics of a low heat rejection diesel engine operating with biodiesel, Renew. Energy. 33 (2008) 1709-1715.

[32] H. Hazar, Cotton methyl ester usage in a diesel engine equipped with insulated combustion chamber, Appl. Energy. 87 (2010) 134-140.

[33] V.K. Murthy, Improving of emissions and performance of rice brawn oil in medium grade low heat rejection diesel engine, Int. J. Renew. Energy Res. 3 (2013) 98-108.

[34] B.R. Prasath, P.T. Porai, M.F. Shabir, Two-zone modeling of diesel/biodiesel blended fuel operated ceramic coated direct injection diesel engine, J. Homepage Www. IJEE. IEEFoundation. Org. 1 (2010) 1039-1056.

[35] A.P. Sathiyagnanam, C.G. Saravanan, S. Dhandapani, Effect of thermal-barrier coating plus fuel additive for reducing emission from di diesel engine, in: Proc. World Congr. Eng., 2010.

[36] D. Srikanth, M.V.S.M. Krishna, P. Ushasri, P.V.K. Murthy, Performance exhaust 
emissions, and combustion characteristics of cotton seed oil based biodiesel in ceramic coated diesel engine, Int. J. Mech. Eng. 2 (2013) 67-82.

[37] Z. Group, Thermal Barrier Coating Provider, (2017). https://www.zircotec.com/products-services/for-motorsport-2/ (accessed December 25, 2017).

[38] P.G. Science, Thermal Barrier Coating Provider, (2017). http://plasmagroup.co.uk/processes/ (accessed December 25, 2017).

[39] A. Feuerstein, J. Knapp, T. Taylor, A. Ashary, A. Bolcavage, N. Hitchman, Technical and economical aspects of current thermal barrier coating systems for gas turbine engines by thermal spray and EBPVD: a review, J. Therm. Spray Technol. 17 (2008) 199-213.

[40] R.A. Miller, Current status of thermal barrier coatings - an overview, Surf. Coatings Technol. 30 (1987) 1-11.

[41] R.A. Churchill, J.E. Smith, N.N. Clark, R.A. Turton, Low-heat rejection engines-a concept review, SAE Tech. Pap. 880014. (1988) 15. doi:10.4271/880014.

[42] S. Jaichandar, P. Tamilporai, Low heat rejection engines-an overview, SAE Tech. Pap. 2003-01-0405. (2003) 17. doi:10.4271/2003-01-0405.

[43] R. Kamo, W. Bryzik, Adiabatic turbocompound engine performance prediction, SAE Tech. Pap. 780068. (1978) 11. doi:10.4271/780068.

[44] I.T. Yilmaz, M. Gumus, M. Akcay, Thermal barrier coatings for diesel engines, in: Int. Sci. Conf., 2010: pp. 19-20.

[45] B. Saint-Ramond, HITS-high insulation thermal barrier coating systems, Air Sp. Eur. 3 (2001) 174-177.

[46] S. Bose, Thermal Barrier Coatings (TBCs), in: High Temp. Coatings, Elsevier Butterworth-Heinemann, Burlington, 2011: pp. 155-232.

[47] M. Cerit, M. Coban, Temperature and thermal stress analyses of a ceramic-coated aluminum alloy piston used in a diesel engine, Int. J. Therm. Sci. 77 (2014) 11-18.

[48] T.M. Yonushonis, Overview of thermal barrier coatings in diesel engines, J. Therm. Spray Technol. 6 (1997) 50-56.

[49] E. Buyukkaya, Thermal analysis of functionally graded coating AlSi alloy and steel pistons, Surf. Coatings Technol. 202 (2008) 3856-3865.

[50] M. Cerit, Thermo mechanical analysis of a partially ceramic coated piston used in an SI engine, Surf. Coatings Technol. 205 (2011) 3499-3505.

[51] E. Buyukkaya, M. Cerit, Thermal analysis of a ceramic coating diesel engine piston using 3-D finite element method, Surf. Coatings Technol. 202 (2007) 398-402.

[52] H.W. Ng, Z. Gan, A finite element analysis technique for predicting as-sprayed residual stresses generated by the plasma spray coating process, Finite Elem. Anal. Des. 41 (2005) 1235-1254.

[53] A.K. Hossain, P.A. Davies, Combustion and emission characteristics of a typical biodiesel engine operated on waste cooking oil derived biodiesel, SAE Tech. Pap. 2012-01-1624. (2012) 8. doi:10.4271/2012-01-1624.

[54] M. Canakci, J.H. Van Gerpen, Comparison of engine performance and emissions for petroleum diesel fuel, yellow grease biodiesel, and soybean oil biodiesel, Trans. ASAE. 46 (2003) 937.

[55] M.P. Dorado, E. Ballesteros, J.M. Arnal, J. Gomez, F.J. Lopez, Exhaust emissions from a Diesel engine fueled with transesterified waste olive oil, Fuel. 82 (2003) 13111315.

[56] D.B. Hulwan, S. V Joshi, Performance, emission and combustion characteristic of a multicylinder DI diesel engine running on diesel--ethanol--biodiesel blends of high ethanol content, Appl. Energy. 88 (2011) 5042-5055. 
[57] L. Zhu, C.S. Cheung, W.G. Zhang, Z. Huang, Combustion, performance and emission characteristics of a DI diesel engine fueled with ethanol--biodiesel blends, Fuel. 90 (2011) 1743-1750.

[58] M.V.S.M. Krishna, T.O. Prakash, P. Ushasri, N. Janardhan, P.V.K. Murthy, Experimental investigations on direct injection diesel engine with ceramic coated combustion chamber with carbureted alcohols and crude jatropha oil, Renew. Sustain. Energy Rev. 53 (2016) 606-628.

[59] D. Srikanth, M.V.S.M. Krishna, P. Ushasri, P.V.K. Murthy, Performance parameters of ceramic coated diesel engine fuelled with cotton seed oil in crude form and biodiesel form, Int. J. Automob. Eng. Res. Dev. 3. (2013) 35-44.

[60] R. Behçet, H. Oktay, A. Çakmak, H. Aydin, Comparison of exhaust emissions of biodiesel--diesel fuel blends produced from animal fats, Renew. Sustain. Energy Rev. 46 (2015) 157-165.

[61] G. Adi, C. Hall, D. Snyder, M. Bunce, C. Satkoski, S. Kumar, P. Garimella, D. Stanton, G. Shaver, Soy-Biodiesel Impact on NO x Emissions and Fuel Economy for Diffusion-Dominated Combustion in a Turbo- Diesel Engine Incorporating Exhaust Gas Recirculation and Common Rail Fuel Injection, Energy \& Fuels. 23 (2009) 58215829.

[62] E. Buyukkaya, Effects of biodiesel on a DI diesel engine performance, emission and combustion characteristics, Fuel. 89 (2010) 3099-3105.

[63] A.N. Ozsezen, M. Canakci, Determination of performance and combustion characteristics of a diesel engine fueled with canola and waste palm oil methyl esters, Energy Convers. Manag. 52 (2011) 108-116.

[64] A. Uzun, M. Akçil, others, Effects of thermal barrier coating on a turbocharged diesel engine performance, Surf. Coatings Technol. 116 (1999) 505-507.

[65] G. De Nicolao, R. Scattolini, C. Siviero, Modelling the volumetric efficiency of IC engines: parametric, non-parametric and neural techniques, Control Eng. Pract. 4 (1996) 1405-1415.

[66] V.K. Domakonda, R.K. Puli, Application of thermal barrier coatings in diesel engines: a review, Energy and Power. 2 (2012) 9-17.

[67] M. Gürü, A. Koca, Ö. Can, C. Çinar, F. Sahin, Biodiesel production from waste chicken fat based sources and evaluation with $\mathrm{Mg}$ based additive in a diesel engine, Renew. Energy. 35 (2010) 637-643.

[68] G. Knothe, C.A. Sharp, T.W. Ryan, Exhaust emissions of biodiesel, petrodiesel, neat methyl esters, and alkanes in a new technology engine, Energy \& Fuels. 20 (2006) 403-408.

[69] H. An, W.M. Yang, S.K. Chou, K.J. Chua, Combustion and emissions characteristics of diesel engine fueled by biodiesel at partial load conditions, Appl. Energy. 99 (2012) $363-371$.

[70] G.A. Olah, A. Goeppert, G.K.S. Prakash, Chemical recycling of carbon dioxide to methanol and dimethyl ether: from greenhouse gas to renewable, environmentally carbon neutral fuels and synthetic hydrocarbons, J. Org. Chem. 74 (2008) 487-498.

[71] M. Çetinkaya, Y. Ulusoy, Y. Tekin, F. Karaosmanoglu, Engine and winter road test performances of used cooking oil originated biodiesel, Energy Convers. Manag. 46 (2005) 1279-1291.

[72] Y. Shiratori, T.Q. Tran, Y. Takahashi, K. Sasaki, Application of biofuels to solid oxide fuel cell, ECS Trans. 35 (2011) 2641-2651.

[73] Z. Utlu, Evaluation of biodiesel fuel obtained from waste cooking oil, Energy Sources, Part A. 29 (2007) 1295-1304.

[74] C. Hasimoglu, Y. Icingur, H. Ogut, Experimental analysis of the effect of exhaust gas 
recirculation (EGR) on engine performance and exhaust emissions on diesel engines, Turkish J. Eng. Environ. Sci. 26 (2002) 127-136.

[75] A.C. Alkidas, R.M. Cole, Gaseous and particulate emissions from a single-cylinder divided-chamber diesel engine, SAE Tech. Pap. 831288. (1983) 15. doi: $10.4271 / 831288$.

[76] E. Büyükkaya, T. Engin, M. Cerit, Effects of thermal barrier coating on gas emissions and performance of a LHR engine with different injection timings and valve adjustments, Energy Convers. Manag. 47 (2006) 1298-1310.

[77] J.M. López, F. Jiménez, F. Aparicio, N. Flores, On-road emissions from urban buses with SCR+ Urea and EGR+ DPF systems using diesel and biodiesel, Transp. Res. Part D Transp. Environ. 14 (2009) 1-5.

[78] X. Shi, Y. Yu, H. He, S. Shuai, H. Dong, R. Li, Combination of biodiesel-ethanoldiesel fuel blend and SCR catalyst assembly to reduce emissions from a heavy-duty diesel engine, J. Environ. Sci. 20 (2008) 177-182. doi:10.1016/S1001-0742(08)600285.

[79] R. Vallinayagam, S. Vedharaj, W.M. Yang, C.G. Saravanan, P.S. Lee, K.J.E. Chua, S.K. Chou, Emission reduction from a diesel engine fueled by pine oil biofuel using SCR and catalytic converter, Atmos. Environ. 80 (2013) 190-197. doi:10.1016/j.atmosenv.2013.07.069.

[80] A.N. Ozsezen, M. Canakci, A. Turkcan, C. Sayin, Performance and combustion characteristics of a DI diesel engine fueled with waste palm oil and canola oil methyl esters, Fuel. 88 (2009) 629-636.

[81] L. Zhu, C.S. Cheung, W.G. Zhang, Z. Huang, Emissions characteristics of a diesel engine operating on biodiesel and biodiesel blended with ethanol and methanol, Sci. Total Environ. 408 (2010) 914-921. 


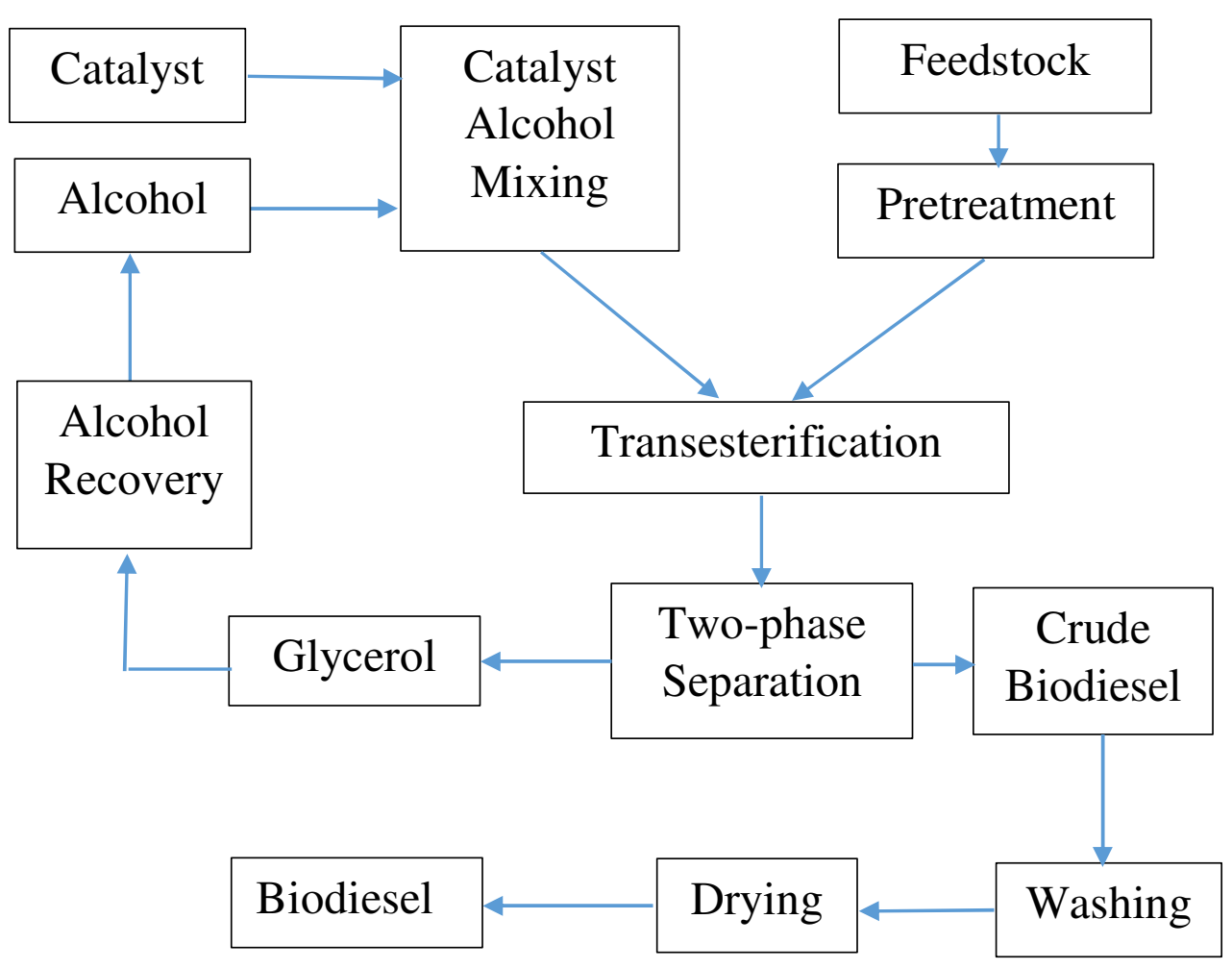

Figure 1: Biodiesel production steps 


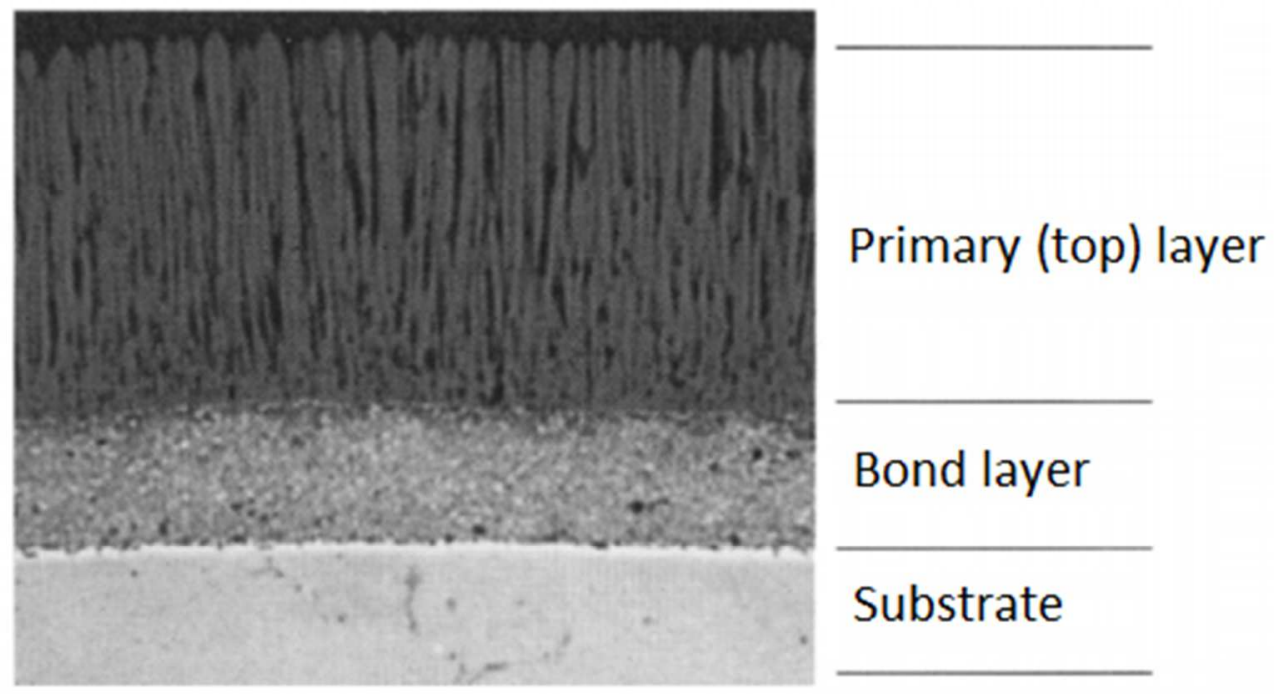

Figure 2: Thermal barrier coating layers [46] 


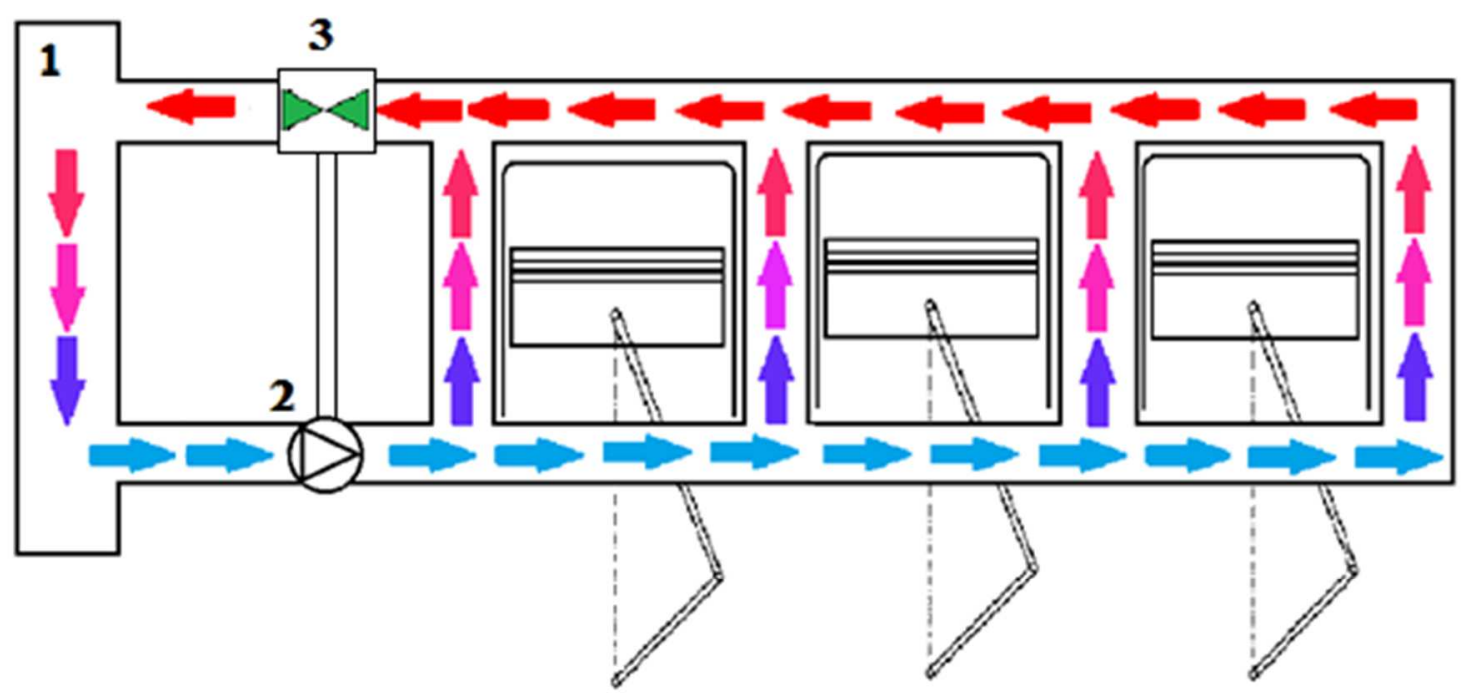

Figure 3: Simple engine cooling system

[1: Radiator, 2: Pump, 3: Thermostat] 


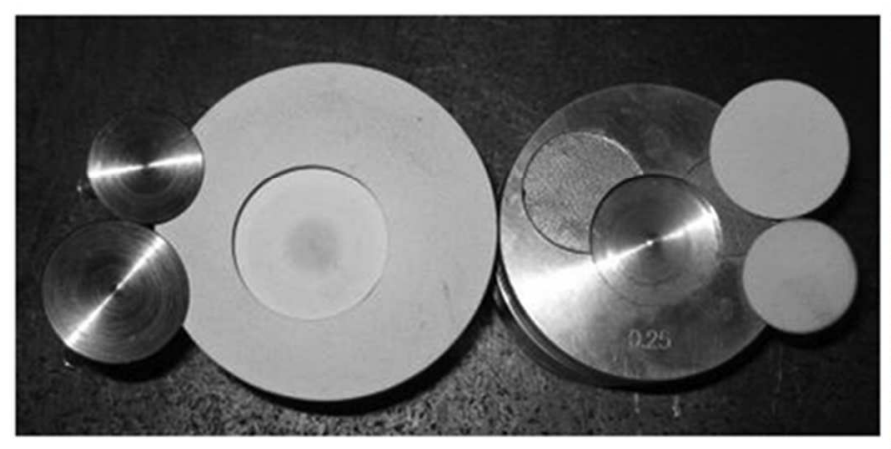

(a)

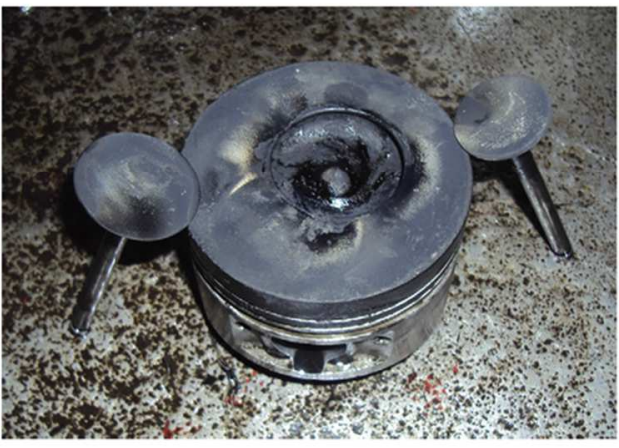

(b)

Figure 4: Ceramic coating without a bond layer (a) before [coated piston crown on the left, uncoated piston crown on the right] and after (b) 100 hours of operation [minor cracks observed] [21] 


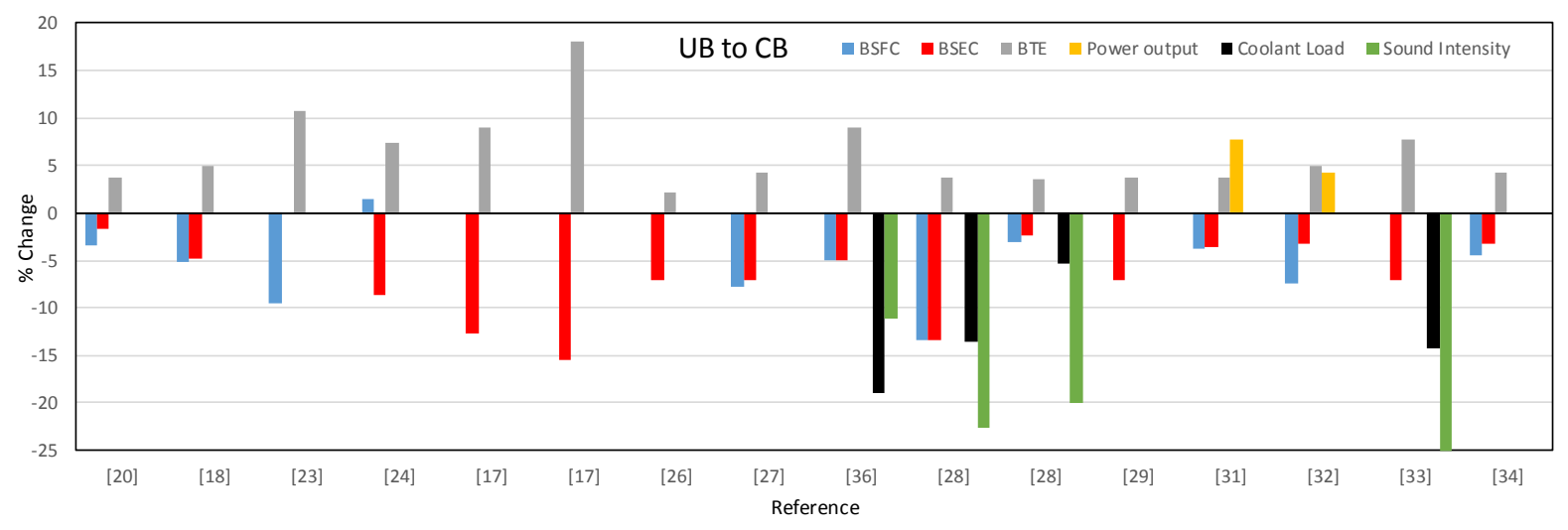

(a) UB to CB scenario

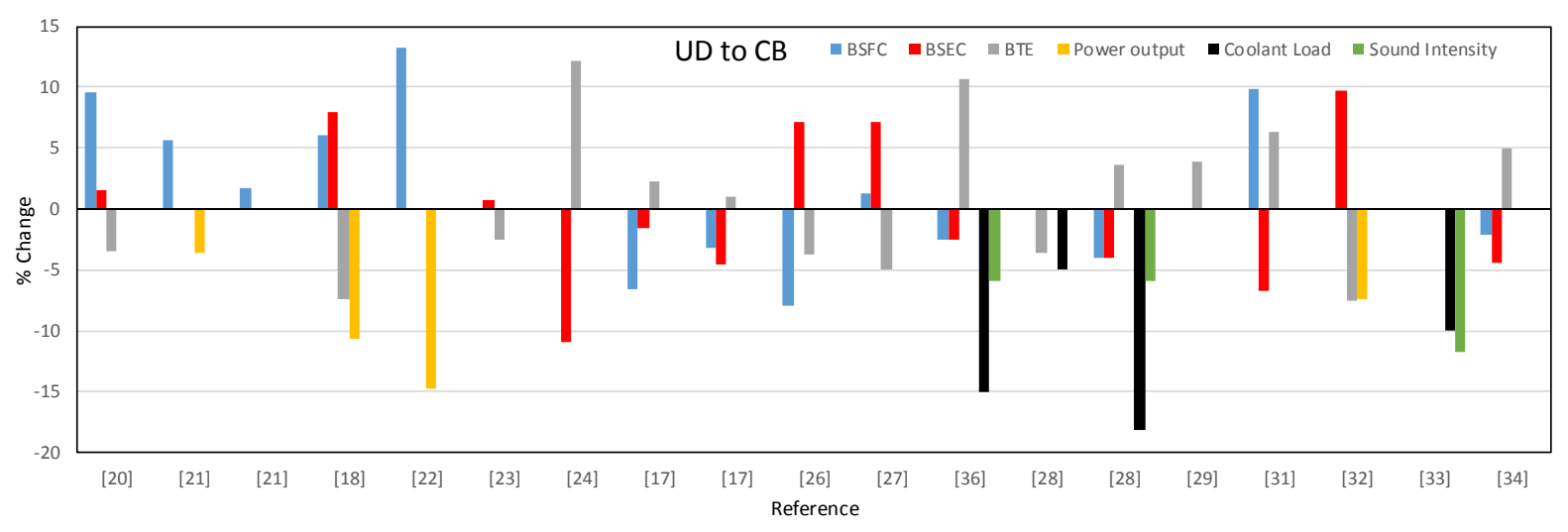

(b) UD to CB scenario

Figure 5: Deviations in engine performance parameters after coating was applied to the engine combustion components 


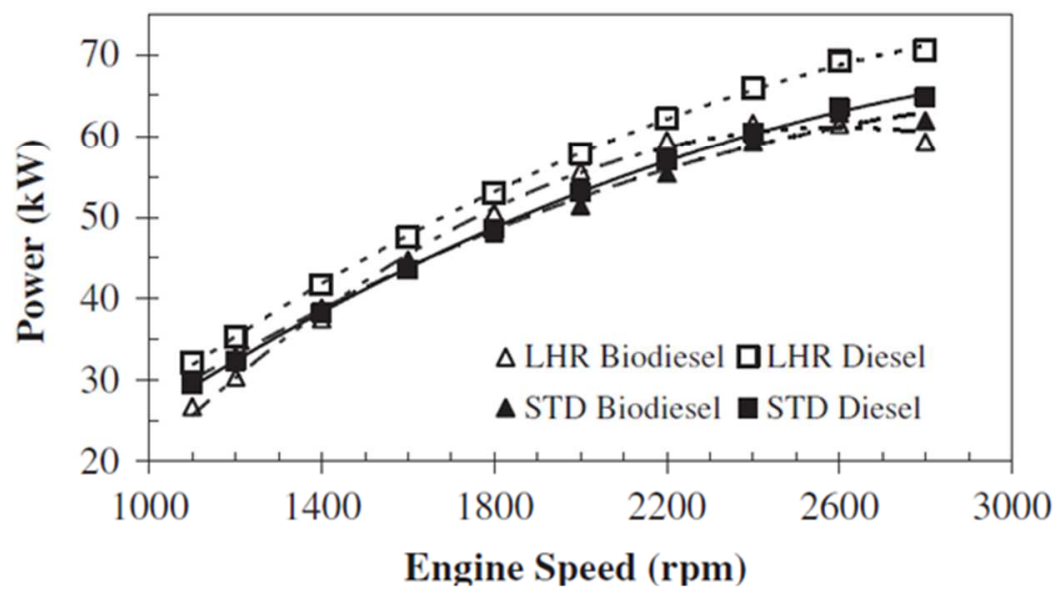

Figure 6: Engine power vs engine speed for UD and CD, UB and CB scenarios [30] 


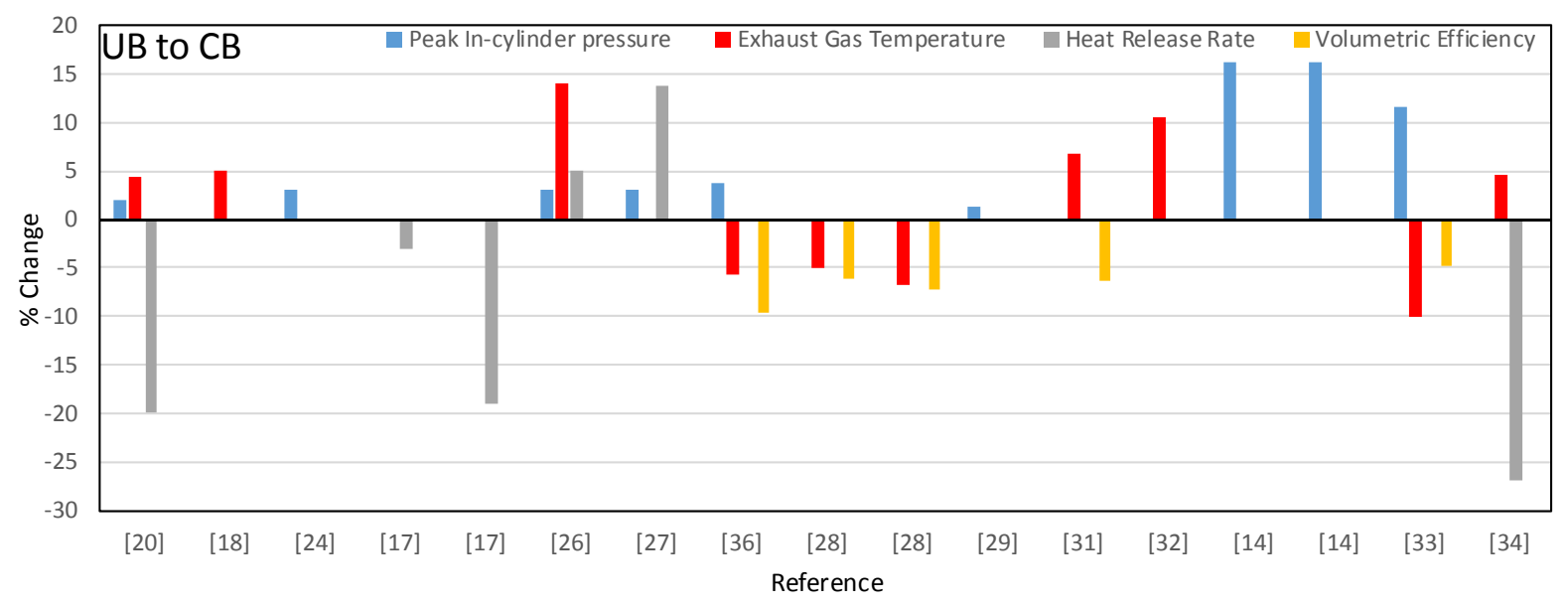

(a) UB to CB scenario

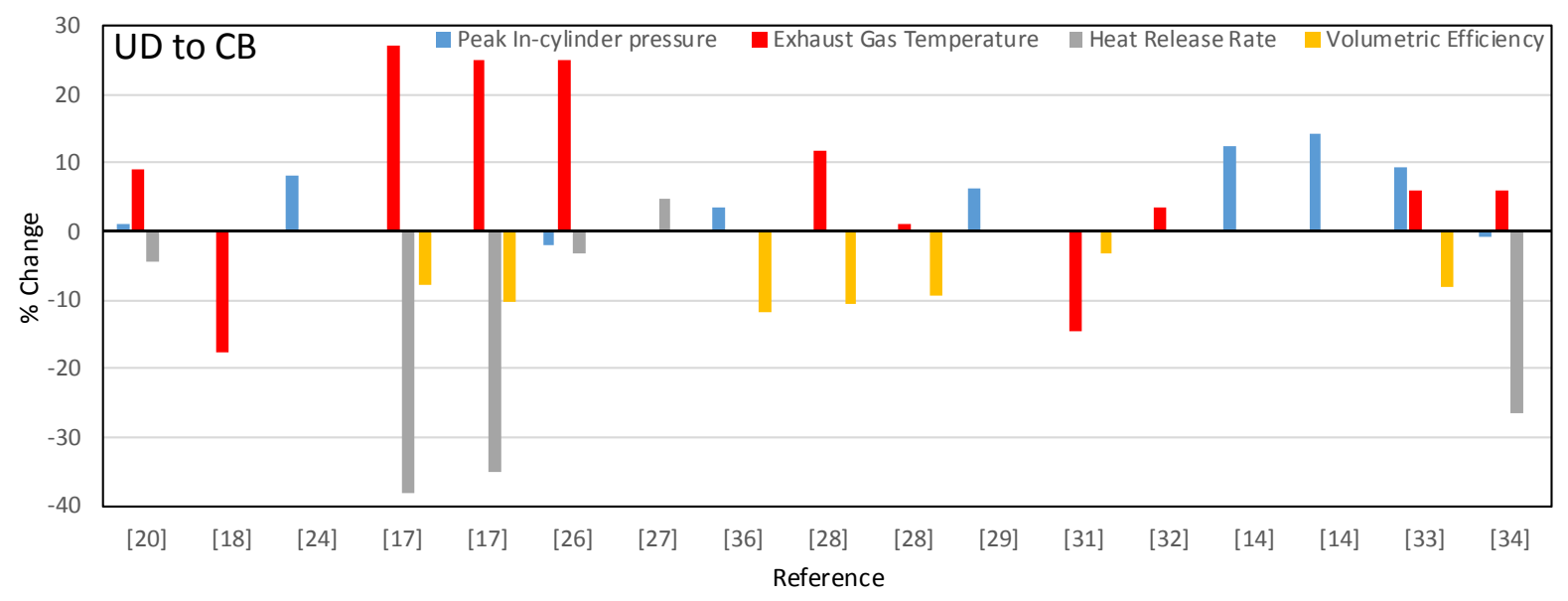

(b) UD to CB scenario

Figure 7: Deviations in engine combustion characteristics before and after thermal barrier coatings were applied 


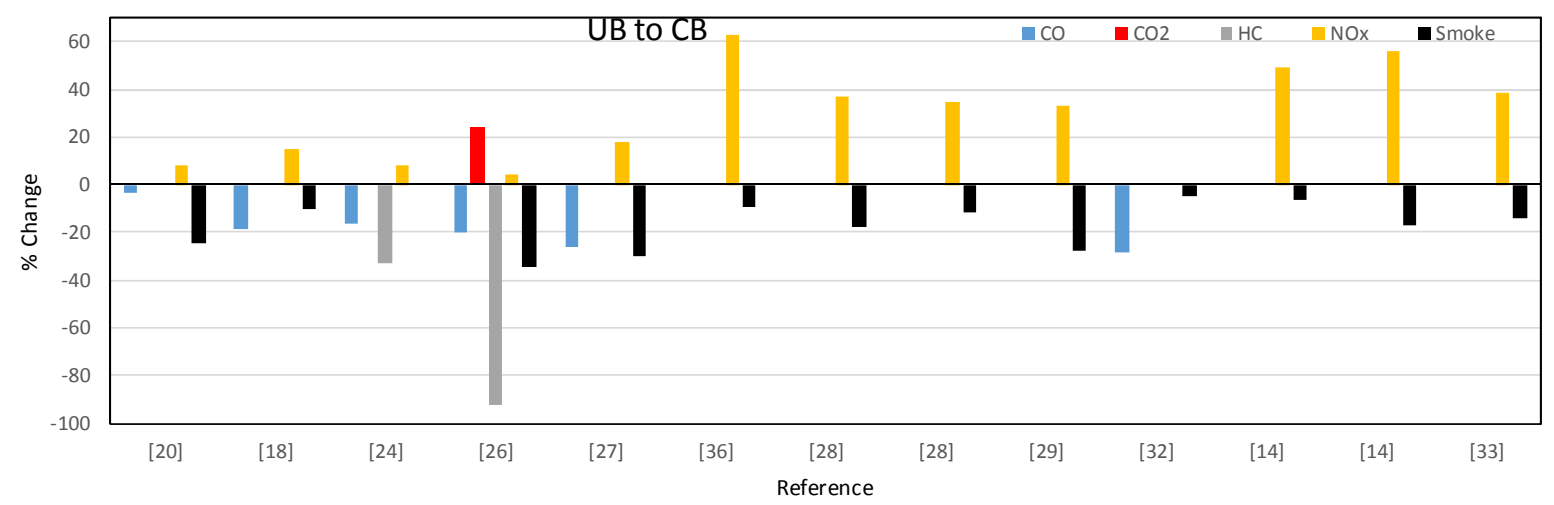

(a) UB to CB scenario

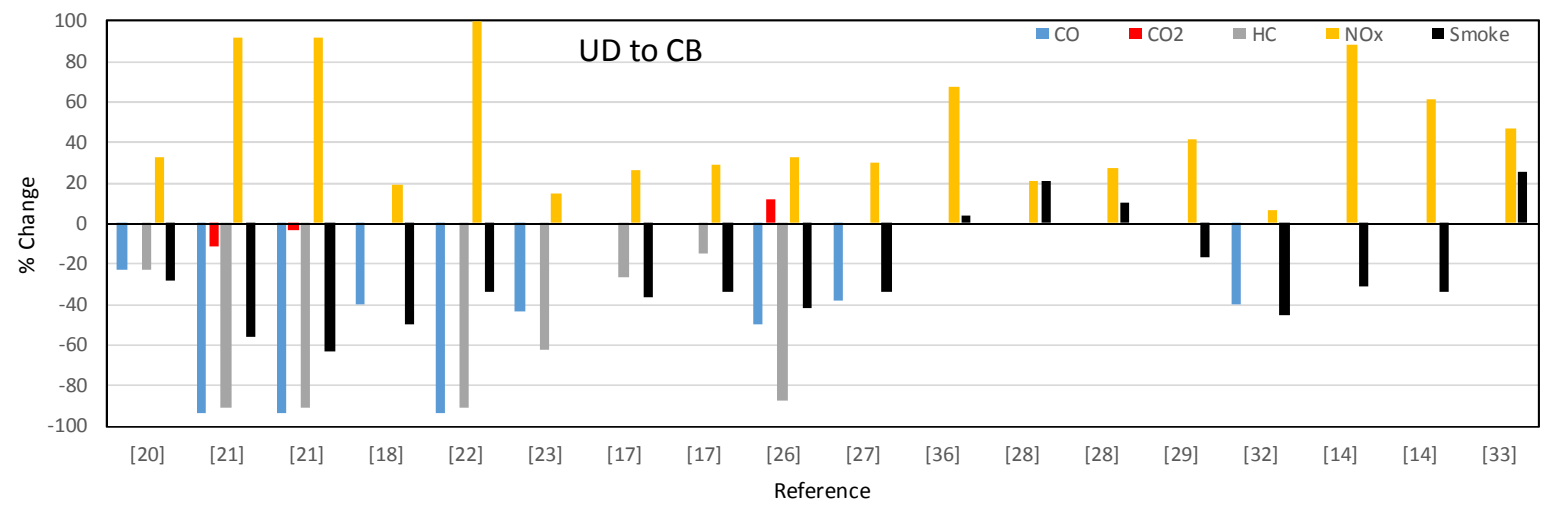

(b) UD to CB scenario

Figure 8: Deviations in exhaust gas emissions and smoke characteristics before and after the TBC modifications 
Table 1: Requirement and effects of material properties of ceramic coating substances [46]

\begin{tabular}{|c|c|c|}
\hline $\begin{array}{l}\text { Material } \\
\text { property }\end{array}$ & $\begin{array}{l}\text { Level of } \\
\text { requirement }\end{array}$ & $\begin{array}{l}\text { Effects and } \\
\text { additional information }\end{array}$ \\
\hline $\begin{array}{l}\text { Thermal } \\
\text { conductivity }\end{array}$ & Low & Aim is to reduce heat rejection \\
\hline Thermal expansion & High & Expansion must be close to substrate and bond coats \\
\hline Melting point & High & Must stand high temperature operation \\
\hline Phase change & Stable & Phase change can destroy the coating layer \\
\hline Oxidation resistance & High & Working fluid can damage components \\
\hline Corrosion resistance & High & Working fluid can damage components \\
\hline Strain tolerance & High & Operating environment imposes large strain ranges \\
\hline
\end{tabular}


Table 2: Properties of popular coating materials $[13,44]$

\begin{tabular}{|c|c|c|c|c|c|c|c|c|}
\hline & \multicolumn{8}{|c|}{ Coating material candidates } \\
\hline & Zirconates & Garnets & Cordierite & $\begin{array}{l}\text { Yittria Stabilized } \\
\text { Zicronia }\end{array}$ & Mullite & Alumina & Spinel & Forsterite \\
\hline & & $\mathrm{YAG}\left(\mathrm{Y}_{3} \mathrm{Al}_{5} \mathrm{O}_{12}\right)$ & $2 \mathrm{MgO}_{2} 2 \mathrm{Al}_{2} \mathrm{O}_{3} .5 \mathrm{SiO}_{2}$ & & & & $\mathrm{MgO} . \mathrm{Al}_{2} \mathrm{O}_{3}$ & $2 \mathrm{MgO} . \mathrm{SiO}_{2}$ \\
\hline \multirow{5}{*}{ 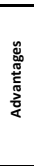 } & SA, low & $\mathrm{TS}, \operatorname{high}\left(1970^{\circ} \mathrm{C}\right)$ & $\mathrm{TC}$, low & TSR high & Density, low & Hardness & TS & TEC, high $\left(11 \times 10^{-6} \mathrm{~K}^{-1}\right)$ \\
\hline & $T C$, low & PS, high & & $\mathrm{TC}$, low & $\mathrm{Ts}$, high & $\mathrm{cl}$ & $\mathrm{Cl}$, good & $\begin{array}{l}\text { Crystallinity after } \\
\text { spray }\end{array}$ \\
\hline & TCR, good & $\mathrm{TC}, \operatorname{low}\left(3 \mathrm{Wm}^{-1} \mathrm{~K}^{-1}\right)$ & & $T E C$, high & PS & OR, good & & \\
\hline & $\begin{array}{l}\text { TEC, high (between } 9 \times 10^{-6} \text { and } 10^{-5} \mathrm{~K} \text { - } \\
\left.{ }_{1}\right)\end{array}$ & OD, low & & & $\mathrm{TC}$, low & & & \\
\hline & & $\begin{array}{l}\text { TEC, high }\left(9.1 \times 10^{-6} \mathrm{~K}-\right. \\
\text { 1) }\end{array}$ & & & Creep and strength, good & & & \\
\hline \multirow{4}{*}{ 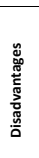 } & & & $A D$ & Sintering above $1473 \mathrm{~K}$ & TEC, low & $\begin{array}{l}\text { TC, relatively } \\
\text { high }\end{array}$ & $\begin{array}{l}\text { TEC, low }\left(7.68 \times 10^{-6} \mathrm{~K}\right. \\
\left.{ }^{1}\right)\end{array}$ & \\
\hline & & & PT & PT at $1443 \mathrm{~K}$ & $\begin{array}{l}\text { Adhesion with substrate, } \\
\text { phor }\end{array}$ & PT at $1273 \mathrm{~K}$ & & \\
\hline & & & $\begin{array}{l}\text { TEC, low }\left(1.67 \times 10^{-6} \mathrm{~K} \text { - }\right. \\
\left.{ }_{1}\right)\end{array}$ & Corrosion \& OT & Crystallisation at $1023-1273 \mathrm{~K}$ & TC, high & & \\
\hline & & & & & & TEC, very low & & \\
\hline
\end{tabular}
Cycling Resistance, TEC: Thermal Expansion Coefficient, TS: Thermal Stability, TSR: Thermal Shock Resistance. 
Table 3: Biofuels (and blends), CI engines and thermal barrier coatings

\begin{tabular}{|c|c|c|c|c|c|c|c|}
\hline \multirow[t]{2}{*}{ Ref } & \multirow[t]{2}{*}{ Fuel } & \multicolumn{4}{|l|}{ COATING } & \multirow{2}{*}{$\begin{array}{l}\text { Engine } \\
\text { Components }\end{array}$} & \multirow{2}{*}{$\begin{array}{l}\text { Air } \\
\text { Intake }\end{array}$} \\
\hline & & $\begin{array}{l}\text { Primary Layer } \\
\text { Material }\end{array}$ & $\begin{array}{c}\text { Thickness } \\
(\mu \mathrm{m})\end{array}$ & $\begin{array}{l}\text { Bond Layer } \\
\text { Material }\end{array}$ & $\begin{array}{c}\text { Thickness } \\
(\mu \mathrm{m})\end{array}$ & & \\
\hline [20] & WCOB & $\mathrm{ZrO}_{2}(88 \%)+\mathrm{Al}_{2} \mathrm{O}_{3}(8 \%)+\mathrm{MgO}(4 \%)$ & 400 & NiCrAl & 100 & $\mathrm{PC}, \mathrm{V}$ & Naturally aspired \\
\hline [21] & $\mathrm{CSO} 35$ & $\mathrm{ZrO}_{2}$ & 200 & & & $\mathrm{CH}, \mathrm{PC}, \mathrm{V}$ & $\mathrm{n} / \mathrm{a}$ \\
\hline [21] & SFO35 & $\mathrm{ZrO}_{2}$ & 200 & & & $\mathrm{CH}, \mathrm{PC}, \mathrm{V}$ & $\mathrm{n} / \mathrm{a}$ \\
\hline [18] & $\mathrm{COB}$ & $\mathrm{Al}_{2} \mathrm{O}_{3}+\mathrm{TiO}_{2}$ & 250 & $\mathrm{NiAl}$ & 50 & $\mathrm{CH}, \mathrm{PC}, \mathrm{V}$ & Naturally aspired \\
\hline [22] & CSO65 & $\mathrm{ZrO}_{2}$ & 400 & $\mathrm{NiCrAl}$ & 100 & $\mathrm{PC}, \mathrm{CL}, \mathrm{V}$ & Naturally aspired \\
\hline [23] & PPOB & $\mathrm{La}_{2} \mathrm{Zr}_{2} \mathrm{O}_{7}$ & 350 & NiCrAlY & 150 & $\mathrm{PC}, \mathrm{CH}, \mathrm{V}$ & Naturally aspired \\
\hline [24] & GNB15 & $\mathrm{ZrO}_{2}+\mathrm{Y}_{2} \mathrm{O}_{3}(8 \%$ by weight $)$ & 200 & $\mathrm{NiCrAl}$ & 100 & $\mathrm{CH}, \mathrm{V}$ & Naturally aspired \\
\hline [17] & RME & Fly Ash & 200 & No bond layer & 0 & $\mathrm{CH}, \mathrm{CL}, \mathrm{PC}, \mathrm{V}$ & Naturally aspired \\
\hline [17] & PME & Fly Ash & 200 & No bond layer & 0 & $\mathrm{CH}, \mathrm{CL}, \mathrm{PC}, \mathrm{V}$ & Naturally aspired \\
\hline [25] & Diesel & $\mathrm{ZrO}_{3}$ & 250 & & & $\mathrm{PC}, \mathrm{CH}$ & $\mathrm{n} / \mathrm{a}$ \\
\hline [26] & PME & $\mathrm{TiO}_{2}$ & 500 & & & PC & Naturally aspired \\
\hline [27] & $\mathrm{JOB}$ & $\mathrm{ZrO}_{3}$ & 350 & $\mathrm{NiCrAl}$ & 150 & $\mathrm{PC}$ & $\mathrm{n} / \mathrm{a}$ \\
\hline [36] & ECSO & PSZ & 500 & & & $\mathrm{CH}$ & Naturally aspired \\
\hline [16] & $\mathrm{n} / \mathrm{a}$ & $\mathrm{CaZrO}_{3}(\mathrm{CH}$ and $\mathrm{V}), \mathrm{MgZrO}_{3}(\mathrm{PC})$ & 350 & $\mathrm{NiCrAl}$ & 150 & $\mathrm{CH}, \mathrm{PC}, \mathrm{V}$ & Turbocharged \\
\hline [28] & MO & PSZ & 500 & & & $\mathrm{CH}$ & Naturally aspired \\
\hline [28] & MOB & PSZ & 500 & & & $\mathrm{CH}$ & Naturally aspired \\
\hline [29] & ТОВ & PSZ & 500 & & & $\mathrm{CH}$ & Naturally aspired \\
\hline [30] & Diesel & $\mathrm{MgO}-\mathrm{ZrO}_{2}(\mathrm{PC}), \mathrm{CaO}-\mathrm{ZrO}_{2}(\mathrm{CH}$ and $\mathrm{V})$ & 350 & $\mathrm{NiCrAl}$ & 150 & $\mathrm{CH}, \mathrm{PC}, \mathrm{V}$ & Turbocharged \\
\hline [31] & SOB & $\mathrm{ZrO}_{3}$ & $\mathrm{n} / \mathrm{a}$ & NiCrAl & $\mathrm{n} / \mathrm{a}$ & $\mathrm{CH}, \mathrm{CL}, \mathrm{PC}, \mathrm{V}$ & Turbocharged \\
\hline [32] & CME40 & Mo & $\mathrm{n} / \mathrm{a}$ & & & $\mathrm{CH}, \mathrm{PC}, \mathrm{V}$ & $\mathrm{n} / \mathrm{a}$ \\
\hline [14] & JO & PSZ & 500 & supreni-90 & $\mathrm{n} / \mathrm{a}$ & $\mathrm{CH}, \mathrm{CL}$ & Naturally aspired \\
\hline [14] & JOB & PSZ & 500 & supreni-90 & $\mathrm{n} / \mathrm{a}$ & $\mathrm{CH}, \mathrm{CL}$ & Naturally aspired \\
\hline [33] & RBO & PSZ & 500 & supreni-90 & $\mathrm{n} / \mathrm{a}$ & $\mathrm{CH}, \mathrm{CL}$ & Naturally aspired \\
\hline [34] & JOB20 & PSZ & 500 & & & $\mathrm{CH}, \mathrm{CL}, \mathrm{PC}, \mathrm{V}$ & Turbocharged \\
\hline [35] & ISO10 & $\mathrm{ZrO}_{2}+\mathrm{Al}_{2} \mathrm{O}_{3}$ & $150+150$ & NiCrALY & 150 & $\mathrm{CH}, \mathrm{CL}, \mathrm{PC}, \mathrm{V}$ & Naturally aspired \\
\hline
\end{tabular}

WCO: Waste Cooking Oil Biodiesel; CSO35: Cottonseed Oil (35\%), Biodiesel + Diesel (65\%); SFO35: Sunflower Oil (35\%), Biodiesel + Diesel (65\%); COB: Corn Oil Biodiesel;

ECSO: Cottonseed Oil Biodiesel; MO: Mohr Oil; MOB: Mohr Oil Biodiesel; TOB: Tobacco Seed Oil Biodiesel; SOB: Sunflower Oil Biodiesel; CME40: Cottonseed Oil (40\%), biodiesel + Diesel (60\%);

JO: Jatropha Oil; JOB: Jatropha Oil Biodiesel; RBO: Rice Brawn Oil; JOB20: Jatropha Oil Biodiesel (20\%) + Diesel (80\%); ISO10: Fuel Additive (Di Iso Propylether 10\%) + Diesel $(90 \%$ );

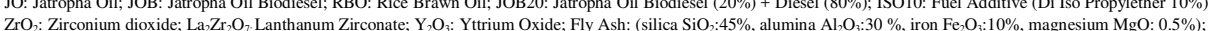

$\mathrm{ZrO}_{3}$ : Partially stabilized Zirconia; PSZ: Partially stabilized Zirconium PSZ; Mo: Molybdenum; CH: Cylinder Head; CL: Cylinder Liner; PC: Piston Crown; V: Intake and Exhaust Valves 
Table 4: Comparison of the engine performance characteristics under coated and uncoated conditions

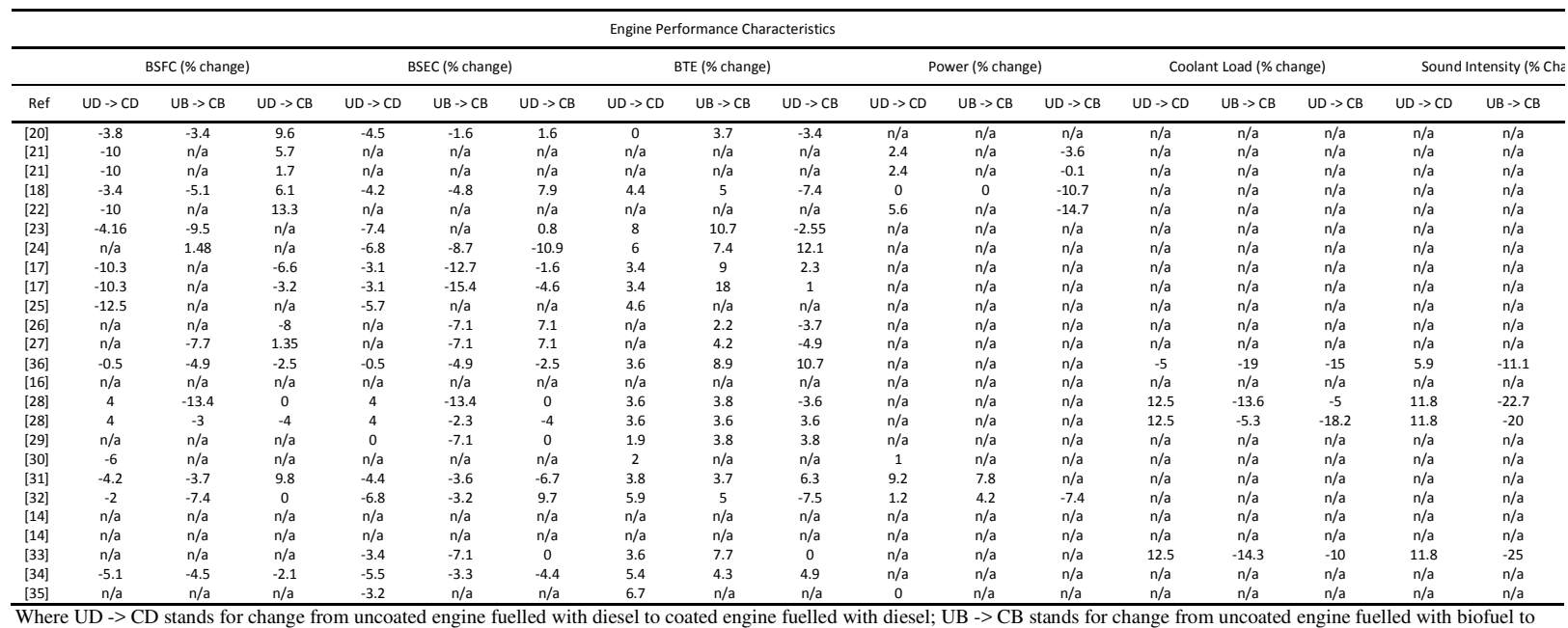
coated engine fuelled with biofuel; and UD $->$ CB represents the change from uncoated engine fuelled with diesel to coated engine fuelled with biofuel. 
Table 5: Effects of injection timing, injector opening pressure and fuel temperature on BSEC characteristics in both uncoated and coated engines

\begin{tabular}{|c|c|c|c|c|c|c|c|c|c|c|c|c|c|c|}
\hline \multirow{5}{*}{ Reference } & \multirow{5}{*}{$\begin{array}{l}\text { Injection } \\
\text { Timing CA } \\
\left({ }^{\circ} \mathrm{bTDC}\right)\end{array}$} & \multirow{5}{*}{ Fuel } & \multicolumn{12}{|c|}{ BSEC at full load (kW/kW) } \\
\hline & & & \multicolumn{6}{|c|}{ Uncoated Engine } & \multicolumn{6}{|c|}{ Coated Engine } \\
\hline & & & \multicolumn{12}{|c|}{ Injection Opening Pressure (bar) } \\
\hline & & & \multicolumn{2}{|c|}{190} & \multicolumn{2}{|c|}{230} & \multicolumn{2}{|c|}{270} & \multicolumn{2}{|c|}{190} & \multicolumn{2}{|c|}{230} & \multicolumn{2}{|c|}{270} \\
\hline & & & NT & PT & NT & PT & NT & PT & NT & PT & NT & PT & NT & PT \\
\hline [36] & 27 & Diesel & 4.00 & $\mathrm{n} / \mathrm{a}$ & 3.96 & $\mathrm{n} / \mathrm{a}$ & 3.92 & $\mathrm{n} / \mathrm{a}$ & 3.98 & $\mathrm{n} / \mathrm{a}$ & 3.92 & $\mathrm{n} / \mathrm{a}$ & 3.88 & $\mathrm{n} / \mathrm{a}$ \\
\hline [36] & 27 & CSOB & 4.10 & 3.90 & 3.90 & 3.80 & 3.80 & 3.70 & 3.90 & 3.86 & 3.86 & 3.82 & 3.82 & 3.78 \\
\hline [36] & 30 & CSOB & 3.92 & 3.88 & 3.88 & 3.84 & 3.84 & 3.80 & 3.82 & 3.78 & 3.78 & 3.74 & 3.74 & 3.70 \\
\hline [36] & 33 & CSOB & 3.86 & 3.82 & 3.90 & 3.86 & 3.92 & 3.88 & $\mathrm{n} / \mathrm{a}$ & $\mathrm{n} / \mathrm{a}$ & $\mathrm{n} / \mathrm{a}$ & $\mathrm{n} / \mathrm{a}$ & $\mathrm{n} / \mathrm{a}$ & $\mathrm{n} / \mathrm{a}$ \\
\hline [36] & 27 & $\mathrm{CSO}$ & 4.20 & 4.00 & 4.00 & 3.94 & 3.94 & 3.92 & 3.92 & 3.90 & 3.90 & 3.86 & 3.86 & 3.82 \\
\hline [28] & 27 & Diesel & 4.00 & $\mathrm{n} / \mathrm{a}$ & 3.92 & $\mathrm{n} / \mathrm{a}$ & 3.84 & $\mathrm{n} / \mathrm{a}$ & 4.16 & $\mathrm{n} / \mathrm{a}$ & 4.08 & $\mathrm{n} / \mathrm{a}$ & 4.00 & $\mathrm{n} / \mathrm{a}$ \\
\hline [28] & 27 & MO & 4.62 & 4.20 & 4.20 & 3.98 & 3.98 & 3.94 & 4.00 & 3.96 & 3.96 & 3.92 & 3.92 & 3.88 \\
\hline [28] & 27 & MOB & 3.96 & 3.92 & 3.92 & 3.88 & 3.88 & 3.84 & 3.84 & 3.80 & 3.80 & 3.76 & 3.76 & 3.72 \\
\hline [28] & 28.5 & MO & 4.58 & 4.54 & 4.54 & 4.50 & 4.50 & 4.45 & 3.98 & 3.94 & 3.94 & 3.90 & 3.90 & 3.86 \\
\hline [28] & 28.5 & MOB & 3.92 & 3.88 & 3.88 & 3.84 & 3.84 & 3.80 & 3.80 & 3.76 & 3.76 & 3.72 & 3.72 & 3.68 \\
\hline [28] & 29.5 & MO & 4.40 & 4.00 & 4.00 & 3.96 & 3.96 & 3.92 & 4.00 & 3.96 & 3.96 & 3.92 & 3.92 & 3.88 \\
\hline [28] & 29.5 & MOB & 3.88 & 3.84 & 3.84 & 3.80 & 3.80 & 3.76 & 3.78 & 3.74 & 3.74 & 3.70 & 3.70 & 3.66 \\
\hline [28] & 30 & MO & 4.00 & 3.96 & 4.20 & 3.98 & 3.98 & 3.94 & 4.00 & 3.96 & 3.96 & 3.92 & 3.92 & 3.88 \\
\hline [28] & 30 & МOB & 3.84 & 3.80 & 3.80 & 3.76 & 3.82 & 3.78 & $\mathrm{n} / \mathrm{a}$ & $\mathrm{n} / \mathrm{a}$ & $\mathrm{n} / \mathrm{a}$ & $\mathrm{n} / \mathrm{a}$ & $\mathrm{n} / \mathrm{a}$ & $\mathrm{n} / \mathrm{a}$ \\
\hline [28] & 31 & MO & 4.20 & 3.98 & 4.00 & 3.96 & 4.20 & 3.98 & $\mathrm{n} / \mathrm{a}$ & $\mathrm{n} / \mathrm{a}$ & $\mathrm{n} / \mathrm{a}$ & $\mathrm{n} / \mathrm{a}$ & $\mathrm{n} / \mathrm{a}$ & $\mathrm{n} / \mathrm{a}$ \\
\hline [28] & 31 & MOB & 3.80 & 3.76 & 3.82 & 3.78 & 3.84 & 3.80 & $\mathrm{n} / \mathrm{a}$ & $\mathrm{n} / \mathrm{a}$ & $\mathrm{n} / \mathrm{a}$ & $\mathrm{n} / \mathrm{a}$ & $\mathrm{n} / \mathrm{a}$ & $\mathrm{n} / \mathrm{a}$ \\
\hline [58] & 27 & Diesel & 4.00 & $\mathrm{n} / \mathrm{a}$ & 3.96 & $\mathrm{n} / \mathrm{a}$ & 3.92 & $\mathrm{n} / \mathrm{a}$ & 4.16 & $\mathrm{n} / \mathrm{a}$ & 4.12 & $\mathrm{n} / \mathrm{a}$ & 4.08 & $\mathrm{n} / \mathrm{a}$ \\
\hline [58] & 27 & JO & 4.30 & $\mathrm{n} / \mathrm{a}$ & 4.26 & $\mathrm{n} / \mathrm{a}$ & 4.22 & $\mathrm{n} / \mathrm{a}$ & 4.00 & $\mathrm{n} / \mathrm{a}$ & 3.96 & $\mathrm{n} / \mathrm{a}$ & 3.92 & $\mathrm{n} / \mathrm{a}$ \\
\hline [58] & 30 & Diesel & $\mathrm{n} / \mathrm{a}$ & $\mathrm{n} / \mathrm{a}$ & $\mathrm{n} / \mathrm{a}$ & $\mathrm{n} / \mathrm{a}$ & $\mathrm{n} / \mathrm{a}$ & $\mathrm{n} / \mathrm{a}$ & 3.88 & $\mathrm{n} / \mathrm{a}$ & 3.84 & $\mathrm{n} / \mathrm{a}$ & 3.80 & $\mathrm{n} / \mathrm{a}$ \\
\hline [58] & 31 & Diesel & 3.60 & $\mathrm{n} / \mathrm{a}$ & 3.64 & $\mathrm{n} / \mathrm{a}$ & 3.68 & $\mathrm{n} / \mathrm{a}$ & $\mathrm{n} / \mathrm{a}$ & $\mathrm{n} / \mathrm{a}$ & $\mathrm{n} / \mathrm{a}$ & $\mathrm{n} / \mathrm{a}$ & $\mathrm{n} / \mathrm{a}$ & $\mathrm{n} / \mathrm{a}$ \\
\hline [58] & 31 & JO & $\mathrm{n} / \mathrm{a}$ & $\mathrm{n} / \mathrm{a}$ & $\mathrm{n} / \mathrm{a}$ & $\mathrm{n} / \mathrm{a}$ & $\mathrm{n} / \mathrm{a}$ & $\mathrm{n} / \mathrm{a}$ & 3.84 & $\mathrm{n} / \mathrm{a}$ & 3.80 & $\mathrm{n} / \mathrm{a}$ & 3.76 & $\mathrm{n} / \mathrm{a}$ \\
\hline [58] & 32 & JO & 3.86 & $\mathrm{n} / \mathrm{a}$ & 3.90 & $\mathrm{n} / \mathrm{a}$ & 3.94 & $\mathrm{n} / \mathrm{a}$ & $\mathrm{n} / \mathrm{a}$ & $\mathrm{n} / \mathrm{a}$ & $\mathrm{n} / \mathrm{a}$ & $\mathrm{n} / \mathrm{a}$ & $\mathrm{n} / \mathrm{a}$ & $\mathrm{n} / \mathrm{a}$ \\
\hline
\end{tabular}


Table 6: Effects of injection parameters and fuel temperature on brake thermal efficiency

\begin{tabular}{|c|c|c|c|c|c|c|c|c|c|c|c|c|c|c|}
\hline \multirow{5}{*}{ Reference } & \multirow{5}{*}{$\begin{array}{c}\text { Injection } \\
\text { Timing CA } \\
\left({ }^{0} \mathrm{bTDC}\right)\end{array}$} & \multirow{5}{*}{ Fuel } & \multicolumn{12}{|c|}{ Maximum BTE (\%) } \\
\hline & & & \multicolumn{6}{|c|}{ Uncoated Engine } & \multicolumn{6}{|c|}{ Coated Engine } \\
\hline & & & \multicolumn{12}{|c|}{ Injection Opening Pressure (bar) } \\
\hline & & & \multicolumn{2}{|c|}{190} & \multicolumn{2}{|c|}{230} & \multicolumn{2}{|c|}{270} & \multicolumn{2}{|c|}{190} & \multicolumn{2}{|c|}{230} & \multicolumn{2}{|c|}{270} \\
\hline & & & NT & PT & NT & PT & NT & PT & NT & PT & NT & PT & NT & PT \\
\hline [36] & 27 & Diesel & 28.0 & $\mathrm{n} / \mathrm{a}$ & 29.0 & $\mathrm{n} / \mathrm{a}$ & 30.0 & $\mathrm{n} / \mathrm{a}$ & 29.0 & $\mathrm{n} / \mathrm{a}$ & 30.0 & $\mathrm{n} / \mathrm{a}$ & 30.5 & $\mathrm{n} / \mathrm{a}$ \\
\hline [36] & 27 & CSOB & 28.0 & 29.0 & 27.5 & 28.0 & 27.0 & 27.5 & 30.5 & 31.0 & 31.0 & 31.5 & 31.5 & 32.0 \\
\hline [36] & 30 & CSOB & $\mathrm{n} / \mathrm{a}$ & $\mathrm{n} / \mathrm{a}$ & $\mathrm{n} / \mathrm{a}$ & $\mathrm{n} / \mathrm{a}$ & $\mathrm{n} / \mathrm{a}$ & $\mathrm{n} / \mathrm{a}$ & 32.0 & 32.5 & 32.5 & 33.0 & 33.0 & 33.5 \\
\hline [36] & 33 & CSOB & 31.0 & 31.5 & 31.0 & 31.5 & 31.0 & 31.5 & $\mathrm{n} / \mathrm{a}$ & $\mathrm{n} / \mathrm{a}$ & $\mathrm{n} / \mathrm{a}$ & $\mathrm{n} / \mathrm{a}$ & $\mathrm{n} / \mathrm{a}$ & $\mathrm{n} / \mathrm{a}$ \\
\hline [59] & 27 & CSO & 27.0 & 28.0 & 28.0 & 29.0 & 29.0 & 30.0 & 29.5 & 30.5 & 30.5 & 31.0 & 31.0 & 31.5 \\
\hline [28] & 27 & Diesel & 28.0 & $\mathrm{n} / \mathrm{a}$ & 29.0 & $\mathrm{n} / \mathrm{a}$ & 30.0 & $\mathrm{n} / \mathrm{a}$ & 29.0 & $\mathrm{n} / \mathrm{a}$ & 30.0 & $\mathrm{n} / \mathrm{a}$ & 30.5 & $\mathrm{n} / \mathrm{a}$ \\
\hline [28] & 27 & MO & 26.0 & 27.0 & 27.0 & 28.0 & 28.0 & 29.0 & 27.0 & 28.0 & 28.0 & 29.0 & 29.0 & 30.0 \\
\hline [28] & 27 & MOB & 28.0 & 29.0 & 29.0 & 30.0 & 30.0 & 31.0 & 29.0 & 30.0 & 30.0 & 31.0 & 31.0 & 32.0 \\
\hline [28] & 28.5 & MO & 26.5 & 27.5 & 27.5 & 28.5 & 28.5 & 29.5 & 28.0 & 29.0 & 29.0 & 30.0 & 30.0 & 31.0 \\
\hline [28] & 28.5 & MOB & 28.5 & 29.5 & 29.5 & 30.5 & 30.5 & 31.5 & 29.0 & 30.0 & 30.0 & 31.0 & 31.0 & 32.0 \\
\hline [28] & 29.5 & MO & 27.0 & 28.0 & 28.0 & 29.0 & 27.0 & 28.0 & $\mathrm{n} / \mathrm{a}$ & $\mathrm{n} / \mathrm{a}$ & $\mathrm{n} / \mathrm{a}$ & $\mathrm{n} / \mathrm{a}$ & $\mathrm{n} / \mathrm{a}$ & $\mathrm{n} / \mathrm{a}$ \\
\hline [28] & 29.5 & MOB & 29.0 & 30.0 & 30.0 & 31.0 & 31.0 & 32.0 & 31.5 & 32.0 & 32.0 & 32.5 & 32.5 & 33.0 \\
\hline [28] & 30 & MO & 28.0 & 29.0 & 27.0 & 28.0 & 26.0 & 27.0 & $\mathrm{n} / \mathrm{a}$ & $\mathrm{n} / \mathrm{a}$ & $\mathrm{n} / \mathrm{a}$ & $\mathrm{n} / \mathrm{a}$ & $\mathrm{n} / \mathrm{a}$ & $\mathrm{n} / \mathrm{a}$ \\
\hline [28] & 30 & MOB & 30.0 & 31.0 & 31.0 & 32.0 & 30.5 & 31.0 & 27.0 & 28.0 & 27.5 & 28.0 & 27.6 & 28.0 \\
\hline [28] & 31 & MO & 27.0 & 28.0 & 26.0 & 27.0 & 25.0 & 26.0 & $\mathrm{n} / \mathrm{a}$ & $\mathrm{n} / \mathrm{a}$ & $\mathrm{n} / \mathrm{a}$ & $\mathrm{n} / \mathrm{a}$ & $\mathrm{n} / \mathrm{a}$ & $\mathrm{n} / \mathrm{a}$ \\
\hline [28] & 31 & MOB & 31.0 & 32.0 & 30.5 & 31.5 & 30.0 & 31.0 & 27.0 & $\mathrm{n} / \mathrm{a}$ & $\mathrm{n} / \mathrm{a}$ & $\mathrm{n} / \mathrm{a}$ & $\mathrm{n} / \mathrm{a}$ & $\mathrm{n} / \mathrm{a}$ \\
\hline [58] & 27 & Diesel & 28.0 & $\mathrm{n} / \mathrm{a}$ & 29.0 & $\mathrm{n} / \mathrm{a}$ & 30.0 & $\mathrm{n} / \mathrm{a}$ & 27.5 & $\mathrm{n} / \mathrm{a}$ & 28.0 & $\mathrm{n} / \mathrm{a}$ & 28.5 & $\mathrm{n} / \mathrm{a}$ \\
\hline [58] & 27 & JO & 25.0 & $\mathrm{n} / \mathrm{a}$ & 26.0 & $\mathrm{n} / \mathrm{a}$ & 27.0 & $\mathrm{n} / \mathrm{a}$ & 29.0 & $\mathrm{n} / \mathrm{a}$ & 29.5 & $\mathrm{n} / \mathrm{a}$ & 30.0 & $\mathrm{n} / \mathrm{a}$ \\
\hline [58] & 30 & Diesel & $\mathrm{n} / \mathrm{a}$ & $\mathrm{n} / \mathrm{a}$ & $\mathrm{n} / \mathrm{a}$ & $\mathrm{n} / \mathrm{a}$ & $\mathrm{n} / \mathrm{a}$ & $\mathrm{n} / \mathrm{a}$ & 28.5 & $\mathrm{n} / \mathrm{a}$ & 29.0 & $\mathrm{n} / \mathrm{a}$ & 29.5 & $\mathrm{n} / \mathrm{a}$ \\
\hline [58] & 31 & Diesel & 31.0 & $\mathrm{n} / \mathrm{a}$ & 30.5 & $\mathrm{n} / \mathrm{a}$ & 30.0 & $\mathrm{n} / \mathrm{a}$ & $\mathrm{n} / \mathrm{a}$ & $\mathrm{n} / \mathrm{a}$ & $\mathrm{n} / \mathrm{a}$ & $\mathrm{n} / \mathrm{a}$ & $\mathrm{n} / \mathrm{a}$ & $\mathrm{n} / \mathrm{a}$ \\
\hline [58] & 31 & $\mathrm{JO}$ & $\mathrm{n} / \mathrm{a}$ & $\mathrm{n} / \mathrm{a}$ & $\mathrm{n} / \mathrm{a}$ & $\mathrm{n} / \mathrm{a}$ & $\mathrm{n} / \mathrm{a}$ & $\mathrm{n} / \mathrm{a}$ & 29.5 & $\mathrm{n} / \mathrm{a}$ & 30.0 & $\mathrm{n} / \mathrm{a}$ & 30.5 & $\mathrm{n} / \mathrm{a}$ \\
\hline [58] & 32 & $\mathrm{JO}$ & 28.0 & $\mathrm{n} / \mathrm{a}$ & 27.0 & $\mathrm{n} / \mathrm{a}$ & 26.0 & $\mathrm{n} / \mathrm{a}$ & $\mathrm{n} / \mathrm{a}$ & $\mathrm{n} / \mathrm{a}$ & $\mathrm{n} / \mathrm{a}$ & $\mathrm{n} / \mathrm{a}$ & $\mathrm{n} / \mathrm{a}$ & $\mathrm{n} / \mathrm{a}$ \\
\hline [33] & 27 & Diesel & 28.0 & $\mathrm{n} / \mathrm{a}$ & 29.0 & $\mathrm{n} / \mathrm{a}$ & 30.0 & $\mathrm{n} / \mathrm{a}$ & 29.0 & $\mathrm{n} / \mathrm{a}$ & 30.0 & $\mathrm{n} / \mathrm{a}$ & 30.5 & $\mathrm{n} / \mathrm{a}$ \\
\hline [33] & 27 & $\mathrm{RBO}$ & 26.0 & 27.0 & 27.0 & 28.0 & 28.0 & 29.0 & 28.0 & 29.0 & 29.0 & 30.0 & 30.0 & 31.0 \\
\hline [33] & 29 & Diesel & 28.5 & $\mathrm{n} / \mathrm{a}$ & 29.5 & $\mathrm{n} / \mathrm{a}$ & 30.2 & $\mathrm{n} / \mathrm{a}$ & 29.5 & $\mathrm{n} / \mathrm{a}$ & 30.5 & $\mathrm{n} / \mathrm{a}$ & 31.0 & $\mathrm{n} / \mathrm{a}$ \\
\hline [33] & 29 & $\mathrm{RBO}$ & 27.0 & 28.0 & 28.0 & 29.0 & 30.0 & 31.0 & 29.0 & 30.0 & 30.0 & 31.0 & 31.0 & 32.0 \\
\hline [33] & 30 & Diesel & 29.0 & $\mathrm{n} / \mathrm{a}$ & 30.0 & $\mathrm{n} / \mathrm{a}$ & 30.5 & $\mathrm{n} / \mathrm{a}$ & 29.0 & $\mathrm{n} / \mathrm{a}$ & 30.0 & $\mathrm{n} / \mathrm{a}$ & 30.5 & $\mathrm{n} / \mathrm{a}$ \\
\hline [33] & 30 & $\mathrm{RBO}$ & 28.0 & 29.0 & 29.0 & 30.0 & 30.0 & 31.0 & 30.5 & 31.5 & 31.5 & 32.5 & 32.5 & 33.5 \\
\hline [33] & 31 & Diesel & 29.5 & $\mathrm{n} / \mathrm{a}$ & 30.0 & $\mathrm{n} / \mathrm{a}$ & 31.0 & $\mathrm{n} / \mathrm{a}$ & $\mathrm{n} / \mathrm{a}$ & $\mathrm{n} / \mathrm{a}$ & $\mathrm{n} / \mathrm{a}$ & $\mathrm{n} / \mathrm{a}$ & $\mathrm{n} / \mathrm{a}$ & $\mathrm{n} / \mathrm{a}$ \\
\hline [33] & 31 & $\mathrm{RBO}$ & 29.0 & 30.0 & 30.0 & 31.0 & 29.0 & 30.0 & 27.0 & 28.0 & 28.0 & 29.0 & 29.0 & 30.0 \\
\hline [33] & 32 & Diesel & 30.0 & $\mathrm{n} / \mathrm{a}$ & 30.5 & $\mathrm{n} / \mathrm{a}$ & 30.5 & $\mathrm{n} / \mathrm{a}$ & $\mathrm{n} / \mathrm{a}$ & $\mathrm{n} / \mathrm{a}$ & $\mathrm{n} / \mathrm{a}$ & $\mathrm{n} / \mathrm{a}$ & $\mathrm{n} / \mathrm{a}$ & $\mathrm{n} / \mathrm{a}$ \\
\hline [33] & 32 & $\mathrm{RBO}$ & 30.0 & 31.0 & 29.0 & 30.0 & 29.0 & 30.0 & $\mathrm{n} / \mathrm{a}$ & $\mathrm{n} / \mathrm{a}$ & $\mathrm{n} / \mathrm{a}$ & $\mathrm{n} / \mathrm{a}$ & $\mathrm{n} / \mathrm{a}$ & $\mathrm{n} / \mathrm{a}$ \\
\hline [33] & 33 & Diesel & 31.0 & $\mathrm{n} / \mathrm{a}$ & 31.0 & $\mathrm{n} / \mathrm{a}$ & 30.0 & $\mathrm{n} / \mathrm{a}$ & $\mathrm{n} / \mathrm{a}$ & $\mathrm{n} / \mathrm{a}$ & $\mathrm{n} / \mathrm{a}$ & $\mathrm{n} / \mathrm{a}$ & $\mathrm{n} / \mathrm{a}$ & $\mathrm{n} / \mathrm{a}$ \\
\hline
\end{tabular}


Table 7: Combustion characteristics in coated and uncoated engines

\begin{tabular}{|c|c|c|c|c|c|c|c|c|c|c|c|c|}
\hline \multicolumn{13}{|c|}{ Combustion Parameters } \\
\hline \multirow[t]{2}{*}{ Ref } & \multicolumn{3}{|c|}{$\begin{array}{l}\text { Peak in-cylinder pressure } \\
\text { (bar change) }\end{array}$} & \multicolumn{3}{|c|}{$\begin{array}{c}\text { Exhaust gas temperature } \\
(\% \text { change })\end{array}$} & \multicolumn{3}{|c|}{$\begin{array}{l}\text { Heat release rate } \\
(\% \text { change) }\end{array}$} & \multicolumn{3}{|c|}{$\begin{array}{l}\text { Volumetric efficiency } \\
\text { ( } \% \text { change) }\end{array}$} \\
\hline & $\mathrm{UD} \rightarrow \mathrm{CD}$ & UB $>$ CB & UD $->C B$ & UD $->C D$ & $\mathrm{UB}->\mathrm{CB}$ & UD $>$ CB & UD $>C D$ & $\mathrm{UB}->\mathrm{CB}$ & UD $->\mathrm{CB}$ & UD $>$ CD & UB $->C B$ & UD $->C B$ \\
\hline$[20]$ & 1 & 2 & 1 & 0 & 4.4 & 9.2 & -2.2 & -20 & -4.3 & $\mathrm{n} / \mathrm{a}$ & $\mathrm{n} / \mathrm{a}$ & $\mathrm{n} / \mathrm{a}$ \\
\hline [21] & $\mathrm{n} / \mathrm{a}$ & $\mathrm{n} / \mathrm{a}$ & $\mathrm{n} / \mathrm{a}$ & $\mathrm{n} / \mathrm{a}$ & $\mathrm{n} / \mathrm{a}$ & $\mathrm{n} / \mathrm{a}$ & $\mathrm{n} / \mathrm{a}$ & $\mathrm{n} / \mathrm{a}$ & $\mathrm{n} / \mathrm{a}$ & $\mathrm{n} / \mathrm{a}$ & $\mathrm{n} / \mathrm{a}$ & $\mathrm{n} / \mathrm{a}$ \\
\hline [21] & $\mathrm{n} / \mathrm{a}$ & $\mathrm{n} / \mathrm{a}$ & $\mathrm{n} / \mathrm{a}$ & $\mathrm{n} / \mathrm{a}$ & $\mathrm{n} / \mathrm{a}$ & $\mathrm{n} / \mathrm{a}$ & $\mathrm{n} / \mathrm{a}$ & $\mathrm{n} / \mathrm{a}$ & $\mathrm{n} / \mathrm{a}$ & $\mathrm{n} / \mathrm{a}$ & $\mathrm{n} / \mathrm{a}$ & $\mathrm{n} / \mathrm{a}$ \\
\hline [18] & $\mathrm{n} / \mathrm{a}$ & $\mathrm{n} / \mathrm{a}$ & $\mathrm{n} / \mathrm{a}$ & 13.7 & 5 & -17.6 & $\mathrm{n} / \mathrm{a}$ & $\mathrm{n} / \mathrm{a}$ & $\mathrm{n} / \mathrm{a}$ & $\mathrm{n} / \mathrm{a}$ & $\mathrm{n} / \mathrm{a}$ & $\mathrm{n} / \mathrm{a}$ \\
\hline [22] & $\mathrm{n} / \mathrm{a}$ & $\mathrm{n} / \mathrm{a}$ & $\mathrm{n} / \mathrm{a}$ & $\mathrm{n} / \mathrm{a}$ & $\mathrm{n} / \mathrm{a}$ & $\mathrm{n} / \mathrm{a}$ & $\mathrm{n} / \mathrm{a}$ & $\mathrm{n} / \mathrm{a}$ & $\mathrm{n} / \mathrm{a}$ & $\mathrm{n} / \mathrm{a}$ & $\mathrm{n} / \mathrm{a}$ & $\mathrm{n} / \mathrm{a}$ \\
\hline [23] & $\mathrm{n} / \mathrm{a}$ & $\mathrm{n} / \mathrm{a}$ & $\mathrm{n} / \mathrm{a}$ & $\mathrm{n} / \mathrm{a}$ & $\mathrm{n} / \mathrm{a}$ & $\mathrm{n} / \mathrm{a}$ & $\mathrm{n} / \mathrm{a}$ & $\mathrm{n} / \mathrm{a}$ & $\mathrm{n} / \mathrm{a}$ & $\mathrm{n} / \mathrm{a}$ & $\mathrm{n} / \mathrm{a}$ & $\mathrm{n} / \mathrm{a}$ \\
\hline [24] & 2 & 3 & 8 & $\mathrm{n} / \mathrm{a}$ & $\mathrm{n} / \mathrm{a}$ & $\mathrm{n} / \mathrm{a}$ & $\mathrm{n} / \mathrm{a}$ & $\mathrm{n} / \mathrm{a}$ & $\mathrm{n} / \mathrm{a}$ & $\mathrm{n} / \mathrm{a}$ & $\mathrm{n} / \mathrm{a}$ & $\mathrm{n} / \mathrm{a}$ \\
\hline [17] & 2.5 & 0 & $\mathrm{n} / \mathrm{a}$ & 22.6 & $\mathrm{n} / \mathrm{a}$ & 27 & 0 & -3 & -38 & -5.5 & $\mathrm{n} / \mathrm{a}$ & -7.7 \\
\hline [17] & 2.5 & 0 & $\mathrm{n} / \mathrm{a}$ & 22.6 & n/a & 25 & 0 & -19 & -35 & -5.5 & $\mathrm{n} / \mathrm{a}$ & -10.2 \\
\hline [25] & $\mathrm{n} / \mathrm{a}$ & $\mathrm{n} / \mathrm{a}$ & $\mathrm{n} / \mathrm{a}$ & 4.2 & $\mathrm{n} / \mathrm{a}$ & $\mathrm{n} / \mathrm{a}$ & $\mathrm{n} / \mathrm{a}$ & $\mathrm{n} / \mathrm{a}$ & $\mathrm{n} / \mathrm{a}$ & $\mathrm{n} / \mathrm{a}$ & $\mathrm{n} / \mathrm{a}$ & $\mathrm{n} / \mathrm{a}$ \\
\hline [26] & $\mathrm{n} / \mathrm{a}$ & 3 & -2 & $\mathrm{n} / \mathrm{a}$ & 14 & 25 & $\mathrm{n} / \mathrm{a}$ & 5 & -3.2 & $\mathrm{n} / \mathrm{a}$ & $\mathrm{n} / \mathrm{a}$ & $\mathrm{n} / \mathrm{a}$ \\
\hline [27] & $\mathrm{n} / \mathrm{a}$ & 3 & 0 & n/a & $\mathrm{n} / \mathrm{a}$ & $\mathrm{n} / \mathrm{a}$ & $\mathrm{n} / \mathrm{a}$ & 13.8 & 4.8 & $\mathrm{n} / \mathrm{a}$ & $\mathrm{n} / \mathrm{a}$ & $\mathrm{n} / \mathrm{a}$ \\
\hline [36] & -2.3 & 3.7 & 3.4 & 8.2 & -5.6 & 0 & $\mathrm{n} / \mathrm{a}$ & $\mathrm{n} / \mathrm{a}$ & $\mathrm{n} / \mathrm{a}$ & -8.2 & -9.6 & -11.8 \\
\hline [16] & $\mathrm{n} / \mathrm{a}$ & $\mathrm{n} / \mathrm{a}$ & $\mathrm{n} / \mathrm{a}$ & $\mathrm{n} / \mathrm{a}$ & $\mathrm{n} / \mathrm{a}$ & $\mathrm{n} / \mathrm{a}$ & -5 to -25 & $\mathrm{n} / \mathrm{a}$ & $\mathrm{n} / \mathrm{a}$ & $\mathrm{n} / \mathrm{a}$ & $\mathrm{n} / \mathrm{a}$ & $\mathrm{n} / \mathrm{a}$ \\
\hline [28] & $\mathrm{n} / \mathrm{a}$ & $\mathrm{n} / \mathrm{a}$ & $\mathrm{n} / \mathrm{a}$ & 8.2 & -5 & 11.8 & $\mathrm{n} / \mathrm{a}$ & $\mathrm{n} / \mathrm{a}$ & $\mathrm{n} / \mathrm{a}$ & -8.2 & -6.2 & -10.6 \\
\hline [28] & $\mathrm{n} / \mathrm{a}$ & $\mathrm{n} / \mathrm{a}$ & $\mathrm{n} / \mathrm{a}$ & 8.2 & -6.7 & 1.2 & $\mathrm{n} / \mathrm{a}$ & $\mathrm{n} / \mathrm{a}$ & $\mathrm{n} / \mathrm{a}$ & -8.2 & -7.2 & -9.4 \\
\hline [29] & -2 & 1.3 & 6.2 & $\mathrm{n} / \mathrm{a}$ & $\mathrm{n} / \mathrm{a}$ & $\mathrm{n} / \mathrm{a}$ & $\mathrm{n} / \mathrm{a}$ & $\mathrm{n} / \mathrm{a}$ & $\mathrm{n} / \mathrm{a}$ & $\mathrm{n} / \mathrm{a}$ & $\mathrm{n} / \mathrm{a}$ & $\mathrm{n} / \mathrm{a}$ \\
\hline [30] & $\mathrm{n} / \mathrm{a}$ & $\mathrm{n} / \mathrm{a}$ & $\mathrm{n} / \mathrm{a}$ & $\mathrm{n} / \mathrm{a}$ & $\mathrm{n} / \mathrm{a}$ & $\mathrm{n} / \mathrm{a}$ & $\mathrm{n} / \mathrm{a}$ & $\mathrm{n} / \mathrm{a}$ & $\mathrm{n} / \mathrm{a}$ & $\mathrm{n} / \mathrm{a}$ & $\mathrm{n} / \mathrm{a}$ & $\mathrm{n} / \mathrm{a}$ \\
\hline [31] & $\mathrm{n} / \mathrm{a}$ & $\mathrm{n} / \mathrm{a}$ & $\mathrm{n} / \mathrm{a}$ & 14.6 & 6.9 & -14.6 & $\mathrm{n} / \mathrm{a}$ & $\mathrm{n} / \mathrm{a}$ & $\mathrm{n} / \mathrm{a}$ & 8.9 & -6.25 & -3.2 \\
\hline [32] & $\mathrm{n} / \mathrm{a}$ & $\mathrm{n} / \mathrm{a}$ & $\mathrm{n} / \mathrm{a}$ & 8 & 10.5 & 3.5 & $\mathrm{n} / \mathrm{a}$ & $\mathrm{n} / \mathrm{a}$ & $\mathrm{n} / \mathrm{a}$ & $\mathrm{n} / \mathrm{a}$ & $\mathrm{n} / \mathrm{a}$ & $\mathrm{n} / \mathrm{a}$ \\
\hline [14] & -4.3 & 16.3 & 12.4 & n/a & $\mathrm{n} / \mathrm{a}$ & n/a & $\mathrm{n} / \mathrm{a}$ & $\mathrm{n} / \mathrm{a}$ & n/a & n/a & $\mathrm{n} / \mathrm{a}$ & $\mathrm{n} / \mathrm{a}$ \\
\hline$[14]$ & -4.3 & 16.2 & 14.4 & $\mathrm{n} / \mathrm{a}$ & $\mathrm{n} / \mathrm{a}$ & $\mathrm{n} / \mathrm{a}$ & $\mathrm{n} / \mathrm{a}$ & $\mathrm{n} / \mathrm{a}$ & $\mathrm{n} / \mathrm{a}$ & $\mathrm{n} / \mathrm{a}$ & $\mathrm{n} / \mathrm{a}$ & $\mathrm{n} / \mathrm{a}$ \\
\hline [33] & -2.3 & 11.7 & 9.4 & 8.2 & -10 & 5.9 & $\mathrm{n} / \mathrm{a}$ & $\mathrm{n} / \mathrm{a}$ & $\mathrm{n} / \mathrm{a}$ & -8.2 & -4.9 & -8.2 \\
\hline [34] & 2.5 & 0 & -0.7 & 5.3 & 4.6 & 6.1 & -26.6 & -27 & -26.4 & $\mathrm{n} / \mathrm{a}$ & $\mathrm{n} / \mathrm{a}$ & $\mathrm{n} / \mathrm{a}$ \\
\hline [35] & $n / a$ & $\mathrm{n} / \mathrm{a}$ & $\mathrm{n} / \mathrm{a}$ & $\mathrm{n} / \mathrm{a}$ & n & D. & $\mathrm{n} / \mathrm{a}$ & n/a & $\mathrm{n} / \mathrm{a}$ & $\mathrm{n} / \mathrm{a}$ & $\mathrm{n} / \mathrm{a}$ & $\mathrm{n} / \mathrm{a}$ \\
\hline
\end{tabular}

with biofel to coated engine fuelled with biofuet, and $\mathrm{UD} \rightarrow \mathrm{CB}$ represents the cheng fom 
Table 8: Effects of injection parameters and fuel temperature on peak in-cylinder pressure, maximum rate of in-cylinder pressure rise and crank angle position at peak in-cylinder pressure

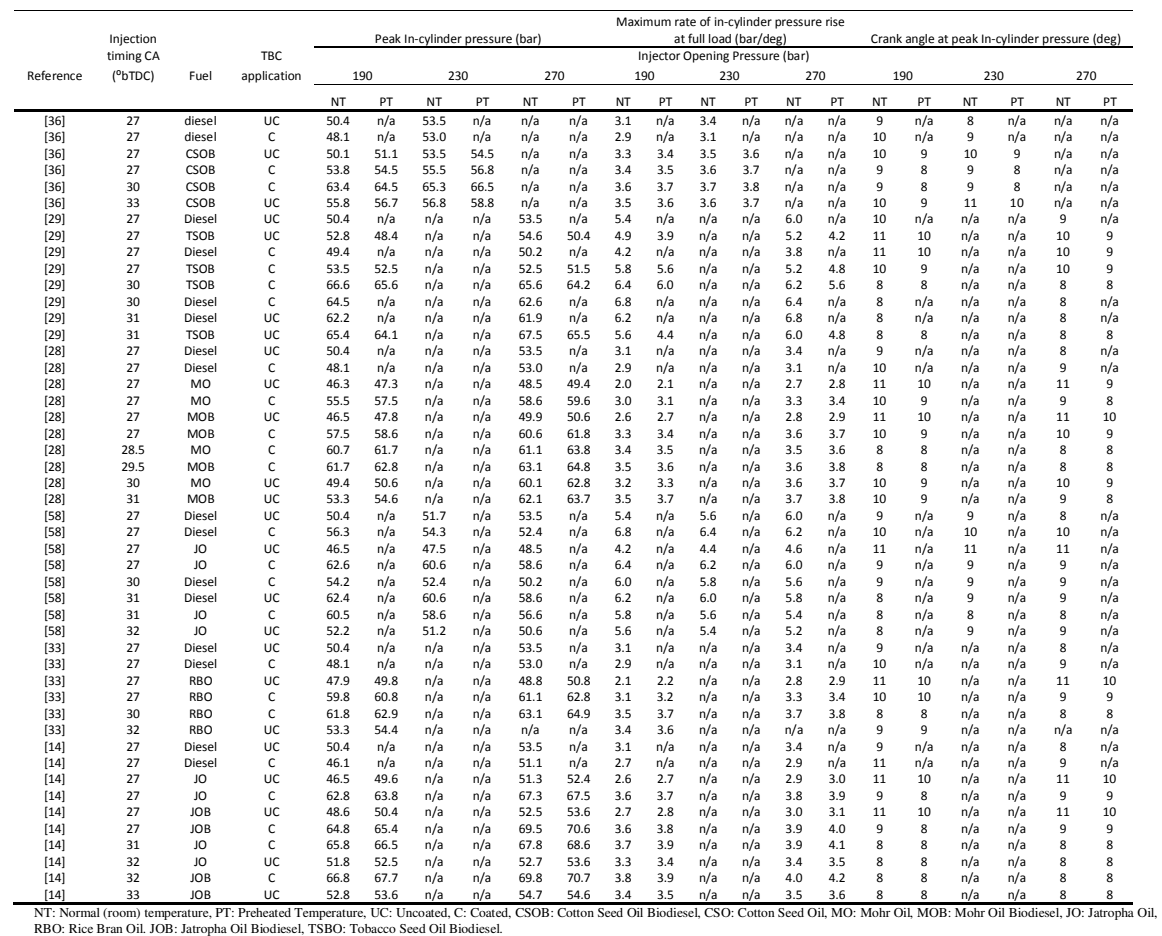


Table 9: Exhaust gas components with and without thermal barrier coatings

\begin{tabular}{|c|c|c|c|c|c|c|c|c|c|c|c|c|c|c|c|}
\hline \multirow[b]{4}{*}{ Ref } & \multicolumn{15}{|c|}{ Exhaust Gas Emissions } \\
\hline & \multicolumn{3}{|c|}{$\mathrm{CO}(\%$ change $)$} & \multicolumn{3}{|c|}{$\mathrm{CO}_{2}(\%$ change $)$} & \multicolumn{3}{|c|}{$\mathrm{HC}(\%$ change $)$} & \multicolumn{3}{|c|}{$\mathrm{NO}_{\mathrm{x}}(\%$ change $)$} & \multicolumn{3}{|c|}{ Smoke (\% change) } \\
\hline & UD -> & UB -> & UD -> & UD -> & UB -> & UD -> & $\begin{array}{l}\text { UD -> } \\
\end{array}$ & UB -> & UD -> & UD -> & UB -> & UD -> & UD -> & UB $->$ & UD -> \\
\hline & $\mathrm{CD}$ & $\mathrm{CB}$ & $\mathrm{CB}$ & $\mathrm{CD}$ & $\mathrm{CB}$ & $\mathrm{CB}$ & $\mathrm{CD}$ & $\mathrm{CB}$ & $\mathrm{CB}$ & $\mathrm{CD}$ & $\mathrm{CB}$ & $\mathrm{CB}$ & $\mathrm{CD}$ & $\mathrm{CB}$ & $\mathrm{CB}$ \\
\hline [20] & -11.4 & -3.6 & -22.9 & $\mathrm{n} / \mathrm{a}$ & $\mathrm{n} / \mathrm{a}$ & $\mathrm{n} / \mathrm{a}$ & $\mathrm{n} / \mathrm{a}$ & $\mathrm{n} / \mathrm{a}$ & -23 & 10 & 8.2 & 32.2 & -25.6 & -24.3 & -28.2 \\
\hline [21] & -813 & $n$ a & -938 & -194 (low \& medium rom) & $n / a$ & -111 & -286 & $n / a$ & -905 & 167 & $n / a$ & 917 & -389 & $n / a$ & -556 \\
\hline [21] & -81.3 & $\mathrm{n} / \mathrm{a}$ & -93.8 & 29.2 (high rpm) & $\mathrm{n} / \mathrm{a}$ & -2.8 & -28.6 & $\mathrm{n} / \mathrm{a}$ & -90.5 & 16.7 & $\mathrm{n} / \mathrm{a}$ & 91.7 & -38.9 & $\mathrm{n} / \mathrm{a}$ & -63 \\
\hline [18] & -27.1 & -18.3 & -39.6 & $\mathrm{n} / \mathrm{a}$ & $\mathrm{n} / \mathrm{a}$ & $\mathrm{n} / \mathrm{a}$ & $\mathrm{n} / \mathrm{a}$ & $\mathrm{n} / \mathrm{a}$ & $\mathrm{n} / \mathrm{a}$ & 3.7 & 14.7 & 18.9 & -9.3 & -10 & -50 \\
\hline [22] & -81.3 & $\begin{array}{l}-10.3 \\
\mathrm{n} / \mathrm{a}\end{array}$ & $\begin{array}{l}-93.8 \\
-93.8\end{array}$ & 列 & 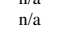 & n/a & $\begin{array}{l}1 / \mathrm{d} \\
-36.4\end{array}$ & a & $\begin{array}{l}-90.9 \\
-9 / 2\end{array}$ & 21.7 & $\mathrm{n} / \mathrm{a}$ & 100 & -33.3 & n/a & -33.3 \\
\hline [23] & -18 & $\mathrm{n} / \mathrm{a}$ & -43.75 & $\mathrm{n} / \mathrm{a}$ & $\mathrm{n} / \mathrm{a}$ & $\mathrm{n} / \mathrm{a}$ & -11.68 & $\mathrm{n} / \mathrm{a}$ & -62.26 & 3.5 & $\mathrm{n} / \mathrm{a}$ & 15 & $\mathrm{n} / \mathrm{a}$ & $\mathrm{n} / \mathrm{a}$ & $\mathrm{n} / \mathrm{a}$ \\
\hline [24] & -14 & -16 & $\mathrm{n} / \mathrm{a}$ & $\mathrm{n} / \mathrm{a}$ & $\mathrm{n} / \mathrm{a}$ & $\mathrm{n} / \mathrm{a}$ & -19 & -33 & $\mathrm{n} / \mathrm{a}$ & 14 & 8 & $\mathrm{n} / \mathrm{a}$ & $\mathrm{n} / \mathrm{a}$ & $\mathrm{n} / \mathrm{a}$ & $\mathrm{n} / \mathrm{a}$ \\
\hline [17] & n/a & n/a & n/a & n & 列 & n/a & -13 & n/a & $\begin{array}{l}\text { ifa } \\
-26.47\end{array}$ & 7.6 & n/a & 26.2 & $\begin{array}{l}\mathrm{n} / \mathrm{a} \\
-29.2\end{array}$ & n & $\begin{array}{c}110 \mathrm{i} \\
-35.9\end{array}$ \\
\hline [17] & $\mathrm{n} / \mathrm{a}$ & $\mathrm{n} / \mathrm{a}$ & $\mathrm{n} / \mathrm{a}$ & $\mathrm{n} / \mathrm{a}$ & $\mathrm{n} / \mathrm{a}$ & $\mathrm{n} / \mathrm{a}$ & -13 & $\mathrm{n} / \mathrm{a}$ & -14.7 & 7.6 & $\mathrm{n} / \mathrm{a}$ & 28.6 & -29.2 & $\mathrm{n} / \mathrm{a}$ & -33.8 \\
\hline [25] & -18.8 & $\mathrm{n} / \mathrm{a}$ & $\mathrm{n} / \mathrm{a}$ & $\mathrm{n} / \mathrm{a}$ & $\mathrm{n} / \mathrm{a}$ & n/a & -9.7 & $\mathrm{n} / \mathrm{a}$ & $\mathrm{n} / \mathrm{a}$ & $\mathrm{n} / \mathrm{a}$ & n/a & $\mathrm{n} / \mathrm{a}$ & -6.13 & $\mathrm{n} / \mathrm{a}$ & $\mathrm{n} / \mathrm{a}$ \\
\hline [26] & $\begin{array}{l}-10.0 \\
\mathrm{n} / \mathrm{a}\end{array}$ & -20 & $\begin{array}{l}-50 \\
-50\end{array}$ & $\mathrm{n} / \mathrm{a}$ & 24 & 12 & $\mathrm{n} / \mathrm{a}$ & $\begin{array}{l}-92.5 \\
-92.5\end{array}$ & $\begin{array}{l}-87 \\
-87\end{array}$ & n/a & 4 & 33 & $\begin{array}{l}0.13 \\
\mathrm{n} / \mathrm{a}\end{array}$ & $\begin{array}{l}-34.4 \\
-\end{array}$ & $\begin{array}{r}-41.6 \\
\end{array}$ \\
\hline [27] & $\mathrm{n} / \mathrm{a}$ & -26.1 & -38 & $\mathrm{n} / \mathrm{a}$ & $\mathrm{n} / \mathrm{a}$ & $\mathrm{n} / \mathrm{a}$ & $\mathrm{n} / \mathrm{a}$ & $\mathrm{n} / \mathrm{a}$ & $\mathrm{n} / \mathrm{a}$ & $\mathrm{n} / \mathrm{a}$ & 17.8 & 30 & $\mathrm{n} / \mathrm{a}$ & -30 & -33.3 \\
\hline [36] & $\mathrm{n} / \mathrm{a}$ & $\mathrm{n} / \mathbf{a}$ & $\mathrm{n} / \mathrm{a}$ & $\mathrm{n} / \mathrm{a}$ & $\mathrm{n} / \mathrm{a}$ & $\mathrm{n} / \mathrm{a}$ & $\mathrm{n} / \mathrm{a}$ & $\mathrm{n} / \mathrm{a}$ & $\mathrm{n} / \mathrm{a}$ & 41.2 & 62.9 & 67.6 & 14.6 & -9.1 & 4.2 \\
\hline [16] & $\mathrm{n} / \mathrm{a}$ & $\mathrm{n} / \mathrm{a}$ & $\mathrm{n} / \mathrm{a}$ & $\mathrm{n} / \mathrm{a}$ & $\mathrm{n} / \mathrm{a}$ & $\mathrm{n} / \mathrm{a}$ & $\mathrm{n} / \mathrm{a}$ & $\mathrm{n} / \mathrm{a}$ & $\mathrm{n} / \mathrm{a}$ & $\mathrm{n} / \mathrm{a}$ & $\mathrm{n} / \mathrm{a}$ & $\mathrm{n} / \mathrm{a}$ & $\mathrm{n} / \mathrm{a}$ & $\mathrm{n} / \mathrm{a}$ & $\mathrm{n} / \mathrm{a}$ \\
\hline [28] & $\mathrm{n} / \mathrm{a}$ & $\mathrm{n} / \mathrm{a}$ & $\mathrm{n} / \mathrm{a}$ & $\mathrm{n} / \mathrm{a}$ & $\mathrm{n} / \mathrm{a}$ & $\mathrm{n} / \mathrm{a}$ & $\mathrm{n} / \mathrm{a}$ & $\mathrm{n} / \mathrm{a}$ & $\mathrm{n} / \mathrm{a}$ & 52.9 & 37.3 & 21.2 & 14.6 & -17.4 & 20.8 \\
\hline [28] & $\mathrm{n} / \mathrm{a}$ & $\mathrm{n} / \mathrm{a}$ & $\mathrm{n} / \mathrm{a}$ & $\mathrm{n} / \mathrm{a}$ & $\mathrm{n} / \mathrm{a}$ & n/a & $\mathrm{n} / \mathrm{a}$ & $\mathrm{n} / \mathrm{a}$ & $\mathrm{n} / \mathrm{a}$ & 52.9 & 35 & 27.1 & 14.6 & -11.7 & 10.4 \\
\hline [29] & $\mathrm{n} / \mathrm{a}$ & $\mathrm{n} / \mathrm{a}$ & $\mathrm{n} / \mathrm{a}$ & $\mathrm{n} / \mathrm{a}$ & $\mathrm{n} / \mathrm{a}$ & n/a & $\mathrm{n} / \mathrm{a}$ & $\mathrm{n} / \mathrm{a}$ & n/a & 29.5 & 33.3 & 41.2 & 14.6 & -27.3 & $\begin{array}{l}0.4 \\
-16.7\end{array}$ \\
\hline [30] & $\mathrm{n} / \mathrm{a}$ & $\mathrm{n} / \mathrm{a}$ & $\mathrm{n} / \mathrm{a}$ & $\mathrm{n} / \mathrm{a}$ & $\mathrm{n} / \mathrm{a}$ & $\mathrm{n} / \mathrm{a}$ & $\mathrm{n} / \mathrm{a}$ & $\mathrm{n} / \mathrm{a}$ & $\mathrm{n} / \mathrm{a}$ & $\mathrm{n} / \mathrm{a}$ & $\mathrm{n} / \mathrm{a}$ & $\mathrm{n} / \mathrm{a}$ & $\mathrm{n} / \mathrm{a}$ & $\mathrm{n} / \mathrm{a}$ & $\mathrm{n} / \mathrm{a}$ \\
\hline [31] & $\mathrm{n} / \mathrm{a}$ & $\mathrm{n} / \mathrm{a}$ & $\mathrm{n} / \mathrm{a}$ & $\mathrm{n} / \mathrm{a}$ & $\mathrm{n} / \mathrm{a}$ & n/a & $\mathrm{n} / \mathrm{a}$ & $\mathrm{n} / \mathrm{a}$ & $\mathrm{n} / \mathrm{a}$ & $\mathrm{n} / \mathrm{a}$ & n/a & $\mathrm{n} / \mathrm{a}$ & $\mathrm{n} / \mathrm{a}$ & $\mathrm{n} / \mathrm{a}$ & n/a \\
\hline [32] & -20.9 & -28.6 & -40.3 & $\mathrm{n} / \mathrm{a}$ & $\mathrm{n} / \mathrm{a}$ & $\mathrm{n} / \mathrm{a}$ & $\mathrm{n} / \mathrm{a}$ & $\mathrm{n} / \mathrm{a}$ & $\mathrm{n} / \mathrm{a}$ & 6.5 & $\mathrm{n} / \mathrm{a}$ & 6.5 & -10 & -5 & -45.7 \\
\hline [14] & $\mathrm{n} / \mathrm{a}$ & $\mathrm{n} / \mathrm{a}$ & $\mathrm{n} / \mathrm{a}$ & $\mathrm{n} / \mathrm{a}$ & $\mathrm{n} / \mathrm{a}$ & $\mathrm{n} / \mathrm{a}$ & $\mathrm{n} / \mathrm{a}$ & $\mathrm{n} / \mathrm{a}$ & $\mathrm{n} / \mathrm{a}$ & 52.9 & 49.4 & 88 & 14.6 & -6.3 & -30.8 \\
\hline [14] & $\mathrm{n} / \mathrm{a}$ & $\mathrm{n} / \mathrm{a}$ & $\mathrm{n} / \mathrm{a}$ & $\mathrm{n} / \mathrm{a}$ & $\mathrm{n} / \mathrm{a}$ & n/a & $\mathrm{n} / \mathrm{a}$ & $\mathrm{n} / \mathrm{a}$ & $\mathrm{n} / \mathrm{a}$ & 52.9 & 55.9 & 61.6 & 14.6 & -16.7 & -33.3 \\
\hline [33] & n/a & n/a & n/a & n/a & $\mathrm{n} / \mathrm{a}$ & n/a & $\mathrm{n} / \mathrm{a}$ & n/a & n/a & 52.9 & $\begin{array}{l}35.9 \\
38.9\end{array}$ & $\begin{array}{c}1.0 \\
47\end{array}$ & $\begin{array}{l}14.0 \\
14.6\end{array}$ & $\begin{array}{l}-10.1 \\
-14.3\end{array}$ & 25 \\
\hline [34] & $\mathrm{n} / \mathrm{a}$ & $\mathrm{n} / \mathrm{a}$ & $\mathrm{n} / \mathrm{a}$ & $\mathrm{n} / \mathrm{a}$ & $\mathrm{n} / \mathrm{a}$ & $\mathrm{n} / \mathrm{a}$ & $\mathrm{n} / \mathrm{a}$ & $\mathrm{n} / \mathrm{a}$ & $\mathrm{n} / \mathrm{a}$ & $\mathrm{n} / \mathrm{a}$ & $\mathrm{n} / \mathrm{a}$ & $\mathrm{n} / \mathrm{a}$ & $\mathrm{n} / \mathrm{a}$ & $n / a$ & $\mathrm{n} / \mathrm{a}$ \\
\hline [35] & $\mathrm{n} / \mathrm{a}$ & $\mathrm{n} / \mathrm{a}$ & $\mathrm{n} / \mathrm{a}$ & $\mathrm{n} / \mathrm{a}$ & $\mathrm{n} / \mathrm{a}$ & $\mathrm{n} / \mathrm{a}$ & $\mathrm{n} / \mathrm{a}$ & $\mathrm{n} / \mathrm{a}$ & $\mathrm{n} / \mathrm{a}$ & -46.5 & $\mathrm{n} / \mathrm{a}$ & $\mathrm{n} / \mathrm{a}$ & 20.7 & $\mathrm{n} / \mathrm{a}$ & $\mathrm{n} / \mathrm{a}$ \\
\hline
\end{tabular}
coated engine fuelled with biofuel; UD $\rightarrow$ CB: change from uncoated engine fuelled with diesel to coated engine fuelled with biofuel. 
Table 10: Effects of injection timing, injector opening pressure and fuel temperature on $\mathrm{NO}_{\mathrm{x}}$ emissions in both uncoated and coated engines

\begin{tabular}{|c|c|c|c|c|c|c|c|c|c|c|c|c|c|c|}
\hline \multirow{5}{*}{ Reference } & \multirow{5}{*}{$\begin{array}{c}\text { Injection } \\
\text { Timing CA } \\
\left({ }^{0} \text { bTDC) }\right.\end{array}$} & \multirow{5}{*}{ Fuel } & \multicolumn{12}{|c|}{$\mathrm{NO}_{\mathrm{x}}$ emission at full load condition (ppm) } \\
\hline & & & \multicolumn{8}{|c|}{ Uncoated Engine } & \multicolumn{4}{|c|}{ Coated Engine } \\
\hline & & & \multicolumn{12}{|c|}{ Injection Opening Pressure (bar) } \\
\hline & & & \multicolumn{2}{|c|}{190} & \multicolumn{2}{|c|}{230} & \multicolumn{2}{|c|}{270} & \multicolumn{2}{|c|}{190} & \multicolumn{2}{|c|}{230} & \multicolumn{2}{|c|}{270} \\
\hline & & & NT & $\mathrm{PT}$ & NT & $\mathrm{PT}$ & NT & PT & NT & PT & NT & PT & NT & PT \\
\hline [36] & 27 & Diesel & 850 & $\mathrm{n} / \mathrm{a}$ & 800 & $\mathrm{n} / \mathrm{a}$ & 750 & $\mathrm{n} / \mathrm{a}$ & 1200 & $\mathrm{n} / \mathrm{a}$ & 1150 & $\mathrm{n} / \mathrm{a}$ & 1100 & $\mathrm{n} / \mathrm{a}$ \\
\hline [36] & 27 & $\mathrm{CSOB}$ & 875 & 825 & 825 & 775 & 775 & 725 & 1425 & 1375 & 1375 & 1325 & 1325 & 1275 \\
\hline [36] & 30 & CSOB & 950 & 900 & 900 & 850 & 850 & 800 & 1325 & 1275 & 1275 & 1225 & 1225 & 1175 \\
\hline [36] & 33 & $\mathrm{CSOB}$ & 1000 & 950 & 950 & 900 & 900 & 850 & $\mathrm{n} / \mathrm{a}$ & $\mathrm{n} / \mathrm{a}$ & $\mathrm{n} / \mathrm{a}$ & $\mathrm{n} / \mathrm{a}$ & $\mathrm{n} / \mathrm{a}$ & $\mathrm{n} / \mathrm{a}$ \\
\hline [29] & 27 & Diesel & 850 & $\mathrm{n} / \mathrm{a}$ & 900 & $\mathrm{n} / \mathrm{a}$ & 950 & $\mathrm{n} / \mathrm{a}$ & 1100 & $\mathrm{n} / \mathrm{a}$ & 1050 & $\mathrm{n} / \mathrm{a}$ & 1000 & $\mathrm{n} / \mathrm{a}$ \\
\hline [29] & 27 & TSOB & 900 & 825 & 950 & 875 & 1000 & 925 & 1200 & 1150 & 1150 & 1100 & 1100 & 1050 \\
\hline [29] & 30 & TSOB & $\mathrm{n} / \mathrm{a}$ & $\mathrm{n} / \mathrm{a}$ & $\mathrm{n} / \mathrm{a}$ & $\mathrm{n} / \mathrm{a}$ & $\mathrm{n} / \mathrm{a}$ & $\mathrm{n} / \mathrm{a}$ & 1150 & 1100 & 1100 & 1050 & 1050 & 1000 \\
\hline [29] & 30 & Diesel & $\mathrm{n} / \mathrm{a}$ & $\mathrm{n} / \mathrm{a}$ & $\mathrm{n} / \mathrm{a}$ & $\mathrm{n} / \mathrm{a}$ & $\mathrm{n} / \mathrm{a}$ & $\mathrm{n} / \mathrm{a}$ & 1050 & $\mathrm{n} / \mathrm{a}$ & 1000 & $\mathrm{n} / \mathrm{a}$ & 950 & $\mathrm{n} / \mathrm{a}$ \\
\hline [29] & 31 & Diesel & 1100 & $\mathrm{n} / \mathrm{a}$ & 1150 & $\mathrm{n} / \mathrm{a}$ & 1200 & $\mathrm{n} / \mathrm{a}$ & $\mathrm{n} / \mathrm{a}$ & $\mathrm{n} / \mathrm{a}$ & $\mathrm{n} / \mathrm{a}$ & $\mathrm{n} / \mathrm{a}$ & $\mathrm{n} / \mathrm{a}$ & $\mathrm{n} / \mathrm{a}$ \\
\hline [29] & 31 & TSOB & 1200 & 1100 & 1250 & 1150 & 1300 & 1250 & $\mathrm{n} / \mathrm{a}$ & $\mathrm{n} / \mathrm{a}$ & $\mathrm{n} / \mathrm{a}$ & $\mathrm{n} / \mathrm{a}$ & $\mathrm{n} / \mathrm{a}$ & $\mathrm{n} / \mathrm{a}$ \\
\hline [28] & 27 & Diesel & 850 & $\mathrm{n} / \mathrm{a}$ & 810 & $\mathrm{n} / \mathrm{a}$ & 770 & $\mathrm{n} / \mathrm{a}$ & 1300 & $\mathrm{n} / \mathrm{a}$ & 1280 & $\mathrm{n} / \mathrm{a}$ & 1260 & $\mathrm{n} / \mathrm{a}$ \\
\hline [28] & 27 & MO & 750 & 700 & 700 & 650 & 650 & 600 & 1030 & 950 & 950 & 900 & 900 & 850 \\
\hline [28] & 27 & MOB & 800 & 750 & 750 & 700 & 700 & 650 & 1080 & 1000 & 1030 & 950 & 980 & 900 \\
\hline [28] & 28.5 & MO & 775 & 725 & 725 & 675 & 675 & 625 & 990 & 910 & 910 & 830 & 830 & 750 \\
\hline [28] & 28.5 & MOB & 825 & 775 & 775 & 725 & 725 & 675 & 1040 & 960 & 960 & 880 & 880 & 800 \\
\hline [28] & 29.5 & $\mathrm{MO}$ & 800 & 750 & 750 & 700 & 700 & 650 & $\mathrm{n} / \mathrm{a}$ & $\mathrm{n} / \mathrm{a}$ & $\mathrm{n} / \mathrm{a}$ & $\mathrm{n} / \mathrm{a}$ & $\mathrm{n} / \mathrm{a}$ & $\mathrm{n} / \mathrm{a}$ \\
\hline [28] & 29.5 & МOB & 850 & 800 & 800 & 750 & 750 & 700 & 1000 & 920 & 920 & 840 & 840 & 760 \\
\hline [28] & 30 & $\mathrm{MO}$ & 850 & 800 & 800 & 750 & 750 & 700 & $\mathrm{n} / \mathrm{a}$ & $\mathrm{n} / \mathrm{a}$ & $\mathrm{n} / \mathrm{a}$ & $\mathrm{n} / \mathrm{a}$ & $\mathrm{n} / \mathrm{a}$ & $\mathrm{n} / \mathrm{a}$ \\
\hline [28] & 30 & MOB & 900 & 850 & 850 & 800 & 800 & 750 & $\mathrm{n} / \mathrm{a}$ & $\mathrm{n} / \mathrm{a}$ & $\mathrm{n} / \mathrm{a}$ & $\mathrm{n} / \mathrm{a}$ & $\mathrm{n} / \mathrm{a}$ & $\mathrm{n} / \mathrm{a}$ \\
\hline [28] & 31 & MO & 900 & 850 & 900 & 850 & 850 & 800 & $\mathrm{n} / \mathrm{a}$ & $\mathrm{n} / \mathrm{a}$ & $\mathrm{n} / \mathrm{a}$ & $\mathrm{n} / \mathrm{a}$ & $\mathrm{n} / \mathrm{a}$ & $\mathrm{n} / \mathrm{a}$ \\
\hline [28] & 31 & МOB & 950 & 800 & 900 & 850 & 850 & 800 & $\mathrm{n} / \mathrm{a}$ & $\mathrm{n} / \mathrm{a}$ & $\mathrm{n} / \mathrm{a}$ & $\mathrm{n} / \mathrm{a}$ & $\mathrm{n} / \mathrm{a}$ & $\mathrm{n} / \mathrm{a}$ \\
\hline [58] & 27 & Diesel & 850 & $\mathrm{n} / \mathrm{a}$ & 900 & $\mathrm{n} / \mathrm{a}$ & 950 & $\mathrm{n} / \mathrm{a}$ & 1100 & $\mathrm{n} / \mathrm{a}$ & 1050 & $\mathrm{n} / \mathrm{a}$ & 1000 & $\mathrm{n} / \mathrm{a}$ \\
\hline [58] & 27 & JO & 750 & $\mathrm{n} / \mathrm{a}$ & 800 & $\mathrm{n} / \mathrm{a}$ & 850 & $\mathrm{n} / \mathrm{a}$ & 1150 & $\mathrm{n} / \mathrm{a}$ & 1100 & $\mathrm{n} / \mathrm{a}$ & 1050 & $\mathrm{n} / \mathrm{a}$ \\
\hline [58] & 30 & Diesel & $\mathrm{n} / \mathrm{a}$ & $\mathrm{n} / \mathrm{a}$ & $\mathrm{n} / \mathrm{a}$ & $\mathrm{n} / \mathrm{a}$ & $\mathrm{n} / \mathrm{a}$ & $\mathrm{n} / \mathrm{a}$ & 1050 & $\mathrm{n} / \mathrm{a}$ & 1000 & $\mathrm{n} / \mathrm{a}$ & 950 & $\mathrm{n} / \mathrm{a}$ \\
\hline [58] & 31 & Diesel & 1100 & $\mathrm{n} / \mathrm{a}$ & 1150 & $\mathrm{n} / \mathrm{a}$ & 1200 & $\mathrm{n} / \mathrm{a}$ & $\mathrm{n} / \mathrm{a}$ & $\mathrm{n} / \mathrm{a}$ & $\mathrm{n} / \mathrm{a}$ & $\mathrm{n} / \mathrm{a}$ & $\mathrm{n} / \mathrm{a}$ & $\mathrm{n} / \mathrm{a}$ \\
\hline [58] & 31 & JO & $\mathrm{n} / \mathrm{a}$ & $\mathrm{n} / \mathrm{a}$ & $\mathrm{n} / \mathrm{a}$ & $\mathrm{n} / \mathrm{a}$ & $\mathrm{n} / \mathrm{a}$ & $\mathrm{n} / \mathrm{a}$ & 1100 & $\mathrm{n} / \mathrm{a}$ & 1050 & $\mathrm{n} / \mathrm{a}$ & 1000 & $\mathrm{n} / \mathrm{a}$ \\
\hline [58] & 32 & $\mathrm{JO}$ & 900 & $\mathrm{n} / \mathrm{a}$ & 950 & $\mathrm{n} / \mathrm{a}$ & 1000 & $\mathrm{n} / \mathrm{a}$ & $\mathrm{n} / \mathrm{a}$ & $\mathrm{n} / \mathrm{a}$ & $\mathrm{n} / \mathrm{a}$ & $\mathrm{n} / \mathrm{a}$ & $\mathrm{n} / \mathrm{a}$ & $\mathrm{n} / \mathrm{a}$ \\
\hline [58] & 27 & Diesel & 850 & $\mathrm{n} / \mathrm{a}$ & 810 & $\mathrm{n} / \mathrm{a}$ & 770 & $\mathrm{n} / \mathrm{a}$ & 1300 & $\mathrm{n} / \mathrm{a}$ & 1280 & $\mathrm{n} / \mathrm{a}$ & 1260 & $\mathrm{n} / \mathrm{a}$ \\
\hline [58] & 27 & RBO & 900 & 850 & 850 & 800 & 800 & 750 & 1250 & 1200 & 1200 & 1150 & 1150 & 1100 \\
\hline [58] & 29 & Diesel & 900 & $\mathrm{n} / \mathrm{a}$ & 860 & $\mathrm{n} / \mathrm{a}$ & 820 & $\mathrm{n} / \mathrm{a}$ & $\mathrm{n} / \mathrm{a}$ & $\mathrm{n} / \mathrm{a}$ & $\mathrm{n} / \mathrm{a}$ & $\mathrm{n} / \mathrm{a}$ & $\mathrm{n} / \mathrm{a}$ & $\mathrm{n} / \mathrm{a}$ \\
\hline [58] & 29 & RBO & 950 & 900 & 900 & 850 & 850 & 800 & 1175 & 1125 & 1125 & 1075 & 1075 & 1025 \\
\hline [58] & 30 & Diesel & 935 & $\mathrm{n} / \mathrm{a}$ & 900 & $\mathrm{n} / \mathrm{a}$ & 860 & $\mathrm{n} / \mathrm{a}$ & 1225 & $\mathrm{n} / \mathrm{a}$ & 1205 & $\mathrm{n} / \mathrm{a}$ & 1185 & $\mathrm{n} / \mathrm{a}$ \\
\hline [58] & 30 & RBO & 1000 & 950 & 950 & 900 & 900 & 850 & 1000 & 950 & 950 & 900 & 900 & 850 \\
\hline [58] & 31 & Diesel & 1020 & $\mathrm{n} / \mathrm{a}$ & 980 & $\mathrm{n} / \mathrm{a}$ & 940 & $\mathrm{n} / \mathrm{a}$ & 1150 & $\mathrm{n} / \mathrm{a}$ & 1130 & $\mathrm{n} / \mathrm{a}$ & 1110 & $\mathrm{n} / \mathrm{a}$ \\
\hline [58] & 31 & RBO & 1050 & 1000 & 1000 & 950 & 950 & 900 & 1100 & 1050 & 1050 & 1000 & 1000 & 950 \\
\hline [58] & 32 & Diesel & 1105 & $\mathrm{n} / \mathrm{a}$ & 1060 & $\mathrm{n} / \mathrm{a}$ & 1020 & $\mathrm{n} / \mathrm{a}$ & $\mathrm{n} / \mathrm{a}$ & $\mathrm{n} / \mathrm{a}$ & $\mathrm{n} / \mathrm{a}$ & $\mathrm{n} / \mathrm{a}$ & $\mathrm{n} / \mathrm{a}$ & $\mathrm{n} / \mathrm{a}$ \\
\hline [58] & 32 & RBO & 1100 & 1050 & 1050 & 1000 & 1000 & 950 & $\mathrm{n} / \mathrm{a}$ & $\mathrm{n} / \mathrm{a}$ & $\mathrm{n} / \mathrm{a}$ & $\mathrm{n} / \mathrm{a}$ & $\mathrm{n} / \mathrm{a}$ & $\mathrm{n} / \mathrm{a}$ \\
\hline [58] & 33 & Diesel & 1190 & $\mathrm{n} / \mathrm{a}$ & 1150 & $\mathrm{n} / \mathrm{a}$ & 1110 & $\mathrm{n} / \mathrm{a}$ & $\mathrm{n} / \mathrm{a}$ & $\mathrm{n} / \mathrm{a}$ & $\mathrm{n} / \mathrm{a}$ & $\mathrm{n} / \mathrm{a}$ & $\mathrm{n} / \mathrm{a}$ & $\mathrm{n} / \mathrm{a}$ \\
\hline [14] & 27 & Diesel & 850 & $\mathrm{n} / \mathrm{a}$ & 890 & $\mathrm{n} / \mathrm{a}$ & 930 & $\mathrm{n}$ & 1300 & $\mathrm{n} / \mathrm{a}$ & 1280 & $\mathrm{n} / \mathrm{a}$ & 1260 & $\mathrm{n} / \mathrm{a}$ \\
\hline [14] & 27 & JO & 675 & 650 & 650 & 600 & 600 & 550 & 1270 & 1230 & 1230 & 1210 & 1180 & 1115 \\
\hline [14] & 27 & $\mathrm{JOB}$ & 820 & 770 & 770 & 720 & 720 & 670 & 1325 & 1275 & 1275 & 1225 & 1225 & 1175 \\
\hline [14] & 30 & JOB & 920 & 870 & 870 & 820 & 820 & 770 & 1300 & 1250 & 1250 & 1200 & 1200 & 1150 \\
\hline [14] & 30 & JO & 750 & 700 & 700 & 650 & 650 & 600 & 1170 & 1150 & 1150 & 1120 & 1120 & 1100 \\
\hline [14] & 31 & $\mathrm{JOB}$ & 970 & 920 & 920 & 870 & 870 & 820 & 1250 & 1200 & 1200 & 1150 & 1150 & 1100 \\
\hline [14] & 31 & $\mathrm{JO}$ & 800 & 750 & 750 & 700 & 700 & 650 & 1070 & 1000 & 1000 & 950 & 950 & 900 \\
\hline [14] & 32 & $\mathrm{JOB}$ & 1020 & 970 & 970 & 920 & 920 & 870 & 1200 & 1150 & 1150 & 1150 & 1150 & 1100 \\
\hline [14] & 32 & $\mathrm{JO}$ & 850 & 800 & 800 & 750 & 750 & 700 & $\mathrm{n} / \mathrm{a}$ & $\mathrm{n} / \mathrm{a}$ & $\mathrm{n} / \mathrm{a}$ & $\mathrm{n} / \mathrm{a}$ & $\mathrm{n} / \mathrm{a}$ & $\mathrm{n} / \mathrm{a}$ \\
\hline [14] & 33 & $\mathrm{JOB}$ & 1110 & 1060 & 1060 & 1010 & 1010 & $\mathrm{n} / \mathrm{a}$ & $\mathrm{n} / \mathrm{a}$ & $\mathrm{n} / \mathrm{a}$ & $\mathrm{n} / \mathrm{a}$ & $\mathrm{n} / \mathrm{a}$ & $\mathrm{n} / \mathrm{a}$ & $\mathrm{n} / \mathrm{a}$ \\
\hline
\end{tabular}


Table 11: Effects of injection parameters and fuel temperature on smoke intensity

\begin{tabular}{|c|c|c|c|c|c|c|c|c|c|c|c|c|c|c|}
\hline \multirow{5}{*}{ Reference } & \multirow{5}{*}{$\begin{array}{l}\text { Injection } \\
\text { Timing } \\
\text { CA } \\
\left({ }^{0} \mathrm{bTDC}\right)\end{array}$} & \multirow{5}{*}{ Fuel } & \multicolumn{12}{|c|}{ Smoke intensity (HSU) full load condition } \\
\hline & & & \multicolumn{6}{|c|}{ Uncoated Engine } & \multicolumn{6}{|c|}{ Coated Engine } \\
\hline & & & \multicolumn{12}{|c|}{ Injection Opening Pressure (bar) } \\
\hline & & & \multicolumn{2}{|c|}{190} & \multicolumn{2}{|c|}{230} & \multicolumn{2}{|c|}{270} & \multicolumn{2}{|c|}{190} & \multicolumn{2}{|c|}{230} & \multicolumn{2}{|c|}{270} \\
\hline & & & NT & PT & NT & PT & NT & PT & NT & PT & NT & PT & NT & PT \\
\hline$[36]$ & 27 & Diesel & 48 & $\mathrm{n} / \mathrm{a}$ & 38 & $\mathrm{n} / \mathrm{a}$ & 34 & $\mathrm{n} / \mathrm{a}$ & 55 & $\mathrm{n} / \mathrm{a}$ & 50 & $\mathrm{n} / \mathrm{a}$ & 45 & $\mathrm{n} / \mathrm{a}$ \\
\hline [36] & 27 & CSOB & 55 & 50 & 50 & 45 & 45 & 40 & 50 & 45 & 45 & 40 & 40 & 35 \\
\hline [36] & 30 & CSOB & $\mathrm{n} / \mathrm{a}$ & $\mathrm{n} / \mathrm{a}$ & $\mathrm{n} / \mathrm{a}$ & $\mathrm{n} / \mathrm{a}$ & $\mathrm{n} / \mathrm{a}$ & $\mathrm{n} / \mathrm{a}$ & 30 & 25 & 25 & 20 & 20 & 15 \\
\hline [36] & 33 & CSOB & 40 & 35 & 45 & 40 & 43 & 40 & $\mathrm{n} / \mathrm{a}$ & $\mathrm{n} / \mathrm{a}$ & $\mathrm{n} / \mathrm{a}$ & $\mathrm{n} / \mathrm{a}$ & $\mathrm{n} / \mathrm{a}$ & $\mathrm{n} / \mathrm{a}$ \\
\hline [29] & 27 & Diesel & 48 & $\mathrm{n} / \mathrm{a}$ & 38 & $\mathrm{n} / \mathrm{a}$ & 34 & $\mathrm{n} / \mathrm{a}$ & 55 & $\mathrm{n} / \mathrm{a}$ & 50 & $\mathrm{n} / \mathrm{a}$ & 45 & $\mathrm{n} / \mathrm{a}$ \\
\hline [29] & 27 & TSOB & 55 & 50 & 50 & 45 & 45 & 40 & 40 & 35 & 35 & 30 & 30 & 25 \\
\hline [29] & 30 & TSOB & $\mathrm{n} / \mathrm{a}$ & $\mathrm{n} / \mathrm{a}$ & $\mathrm{n} / \mathrm{a}$ & $\mathrm{n} / \mathrm{a}$ & $\mathrm{n} / \mathrm{a}$ & $\mathrm{n} / \mathrm{a}$ & 35 & 30 & 30 & 25 & 25 & 20 \\
\hline [29] & 30 & Diesel & $\mathrm{n} / \mathrm{a}$ & $\mathrm{n} / \mathrm{a}$ & $\mathrm{n} / \mathrm{a}$ & $\mathrm{n} / \mathrm{a}$ & $\mathrm{n} / \mathrm{a}$ & $\mathrm{n} / \mathrm{a}$ & 50 & $\mathrm{n} / \mathrm{a}$ & 45 & $\mathrm{n} / \mathrm{a}$ & 40 & $\mathrm{n} / \mathrm{a}$ \\
\hline [29] & 31 & Diesel & 30 & $\mathrm{n} / \mathrm{a}$ & 30 & $\mathrm{n} / \mathrm{a}$ & 35 & $\mathrm{n} / \mathrm{a}$ & $\mathrm{n} / \mathrm{a}$ & $\mathrm{n} / \mathrm{a}$ & $\mathrm{n} / \mathrm{a}$ & $\mathrm{n} / \mathrm{a}$ & $\mathrm{n} / \mathrm{a}$ & $\mathrm{n} / \mathrm{a}$ \\
\hline [29] & 31 & TSOB & 45 & 40 & 40 & 35 & 35 & 30 & $\mathrm{n} / \mathrm{a}$ & $\mathrm{n} / \mathrm{a}$ & $\mathrm{n} / \mathrm{a}$ & $\mathrm{n} / \mathrm{a}$ & $\mathrm{n} / \mathrm{a}$ & $\mathrm{n} / \mathrm{a}$ \\
\hline [28] & 27 & Diesel & 85 & $\mathrm{n} / \mathrm{a}$ & 80 & $\mathrm{n} / \mathrm{a}$ & 75 & $\mathrm{n} / \mathrm{a}$ & 95 & $\mathrm{n} / \mathrm{a}$ & 90 & $\mathrm{n} / \mathrm{a}$ & 85 & $\mathrm{n} / \mathrm{a}$ \\
\hline [28] & 27 & MO & 110 & 105 & 105 & 103 & 100 & 95 & 85 & 80 & 80 & 75 & 75 & 70 \\
\hline [28] & 27 & MOB & 100 & 95 & 98 & 93 & 96 & 91 & 80 & 75 & 75 & 70 & 70 & 65 \\
\hline [28] & 28.5 & MO & 109 & 104 & 104 & 102 & 99 & 94 & 80 & 75 & 75 & 70 & 70 & 65 \\
\hline [28] & 28.5 & MOB & 99 & 94 & 94 & 92 & 89 & 84 & 75 & 70 & 70 & 65 & 65 & 60 \\
\hline [28] & 29.5 & MO & 107 & 102 & 104 & 99 & 94 & 97 & 85 & 80 & 80 & 75 & 75 & 70 \\
\hline [28] & 29.5 & MOB & 97 & 92 & 92 & 87 & 91 & 86 & 65 & 60 & 60 & 55 & 55 & 50 \\
\hline [28] & 30 & MO & 104 & 100 & 102 & 97 & 110 & 105 & $\mathrm{n} / \mathrm{a}$ & $\mathrm{n} / \mathrm{a}$ & $\mathrm{n} / \mathrm{a}$ & $\mathrm{n} / \mathrm{a}$ & $\mathrm{n} / \mathrm{a}$ & $\mathrm{n} / \mathrm{a}$ \\
\hline [28] & 30 & MOB & 94 & 89 & 92 & 87 & 90 & 85 & $\mathrm{n} / \mathrm{a}$ & $\mathrm{n} / \mathrm{a}$ & $\mathrm{n} / \mathrm{a}$ & $\mathrm{n} / \mathrm{a}$ & $\mathrm{n} / \mathrm{a}$ & $\mathrm{n} / \mathrm{a}$ \\
\hline [28] & 31 & MO & 102 & 97 & 105 & 100 & 110 & 105 & $\mathrm{n} / \mathrm{a}$ & $\mathrm{n} / \mathrm{a}$ & $\mathrm{n} / \mathrm{a}$ & $\mathrm{n} / \mathrm{a}$ & $\mathrm{n} / \mathrm{a}$ & $\mathrm{n} / \mathrm{a}$ \\
\hline [28] & 31 & MOB & 92 & 87 & 90 & 85 & 93 & 87 & $\mathrm{n} / \mathrm{a}$ & $\mathrm{n} / \mathrm{a}$ & $\mathrm{n} / \mathrm{a}$ & $\mathrm{n} / \mathrm{a}$ & $\mathrm{n} / \mathrm{a}$ & $\mathrm{n} / \mathrm{a}$ \\
\hline [33] & 27 & Diesel & 48 & $\mathrm{n} / \mathrm{a}$ & 38 & $\mathrm{n} / \mathrm{a}$ & 34 & $\mathrm{n} / \mathrm{a}$ & 55 & $\mathrm{n} / \mathrm{a}$ & 50 & $\mathrm{n} / \mathrm{a}$ & 45 & $\mathrm{n} / \mathrm{a}$ \\
\hline [33] & 27 & RBO & 70 & 65 & 65 & 60 & 63 & 60 & 60 & 55 & 55 & 50 & 50 & 45 \\
\hline [33] & 29 & Diesel & 40 & $\mathrm{n} / \mathrm{a}$ & 36 & $\mathrm{n} / \mathrm{a}$ & 34 & $\mathrm{n} / \mathrm{a}$ & 52 & $\mathrm{n} / \mathrm{a}$ & 48 & $\mathrm{n} / \mathrm{a}$ & 43 & $\mathrm{n} / \mathrm{a}$ \\
\hline [33] & 29 & $\mathrm{RBO}$ & 68 & 64 & 63 & 59 & 60 & 57 & 55 & 50 & 50 & 45 & 45 & 40 \\
\hline [33] & 30 & Diesel & 36 & $\mathrm{n} / \mathrm{a}$ & 34 & $\mathrm{n} / \mathrm{a}$ & 32 & $\mathrm{n} / \mathrm{a}$ & 45 & $\mathrm{n} / \mathrm{a}$ & 42 & $\mathrm{n} / \mathrm{a}$ & 41 & $\mathrm{n} / \mathrm{a}$ \\
\hline [33] & 30 & $\mathrm{RBO}$ & 67 & 64 & 60 & 57 & 61 & 58 & 46 & 42 & 42 & 40 & 40 & 38 \\
\hline [33] & 31 & Diesel & 33 & $\mathrm{n} / \mathrm{a}$ & 32 & $\mathrm{n} / \mathrm{a}$ & 30 & $\mathrm{n} / \mathrm{a}$ & 43 & $\mathrm{n} / \mathrm{a}$ & 41 & $\mathrm{n} / \mathrm{a}$ & 40 & $\mathrm{n} / \mathrm{a}$ \\
\hline [33] & 31 & $\mathrm{RBO}$ & 60 & 57 & 57 & 54 & 54 & 60 & 55 & 50 & 50 & 45 & 45 & 40 \\
\hline [33] & 32 & Diesel & 32 & $\mathrm{n} / \mathrm{a}$ & 31 & $\mathrm{n} / \mathrm{a}$ & 32 & $\mathrm{n} / \mathrm{a}$ & $\mathrm{n} / \mathrm{a}$ & $\mathrm{n} / \mathrm{a}$ & $\mathrm{n} / \mathrm{a}$ & $\mathrm{n} / \mathrm{a}$ & $\mathrm{n} / \mathrm{a}$ & $\mathrm{n} / \mathrm{a}$ \\
\hline [33] & 32 & $\mathrm{RBO}$ & 50 & 45 & 45 & 40 & 40 & 35 & $\mathrm{n} / \mathrm{a}$ & $\mathrm{n} / \mathrm{a}$ & $\mathrm{n} / \mathrm{a}$ & $\mathrm{n} / \mathrm{a}$ & $\mathrm{n} / \mathrm{a}$ & $\mathrm{n} / \mathrm{a}$ \\
\hline [33] & 33 & Diesel & 30 & $\mathrm{n} / \mathrm{a}$ & 30 & $\mathrm{n} / \mathrm{a}$ & 35 & $\mathrm{n} / \mathrm{a}$ & $\mathrm{n} / \mathrm{a}$ & $\mathrm{n} / \mathrm{a}$ & $\mathrm{n} / \mathrm{a}$ & $\mathrm{n} / \mathrm{a}$ & $\mathrm{n} / \mathrm{a}$ & $\mathrm{n} / \mathrm{a}$ \\
\hline [14] & 27 & Diesel & 48 & $\mathrm{n} / \mathrm{a}$ & 38 & $\mathrm{n} / \mathrm{a}$ & 34 & $\mathrm{n} / \mathrm{a}$ & 55 & $\mathrm{n} / \mathrm{a}$ & 50 & $\mathrm{n} / \mathrm{a}$ & 45 & $\mathrm{n} / \mathrm{a}$ \\
\hline [14] & 27 & $\mathrm{JO}$ & 65 & 60 & 63 & 58 & 58 & 54 & 45 & 40 & 40 & 35 & 35 & 30 \\
\hline [14] & 27 & JOB & 60 & 55 & 55 & 50 & 50 & 45 & 40 & 35 & 35 & 30 & 30 & 25 \\
\hline [14] & 30 & JOB & 55 & 50 & 50 & 45 & 45 & 40 & 35 & 30 & 30 & 25 & 25 & 20 \\
\hline [14] & 30 & $\mathrm{JO}$ & 60 & 55 & 55 & 50 & 45 & 55 & 40 & 35 & 35 & 30 & 30 & 25 \\
\hline [14] & 31 & JOB & 50 & 45 & 45 & 40 & 40 & 35 & 30 & 25 & 25 & 20 & 20 & 18 \\
\hline [14] & 31 & $\mathrm{JO}$ & 55 & 50 & 50 & 45 & 55 & 52 & 35 & 30 & 30 & 25 & 25 & 22 \\
\hline [14] & 32 & JOB & 45 & 40 & 40 & 35 & 45 & 40 & 25 & 20 & 25 & 20 & 20 & 16 \\
\hline [14] & 32 & JO & 50 & 45 & 55 & 52 & 52 & 49 & $\mathrm{n} / \mathrm{a}$ & $\mathrm{n} / \mathrm{a}$ & $\mathrm{n} / \mathrm{a}$ & $\mathrm{n} / \mathrm{a}$ & $\mathrm{n} / \mathrm{a}$ & $\mathrm{n} / \mathrm{a}$ \\
\hline [14] & 33 & JOB & 40 & 35 & 45 & 40 & 50 & 45 & $\mathrm{n} / \mathrm{a}$ & $\mathrm{n} / \mathrm{a}$ & $\mathrm{n} / \mathrm{a}$ & $\mathrm{n} / \mathrm{a}$ & $\mathrm{n} / \mathrm{a}$ & $\mathrm{n} / \mathrm{a}$ \\
\hline
\end{tabular}


